\begin{tabular}{|c|c|c|c|}
\hline Article Info & \multicolumn{2}{|c|}{ RESEARCH ARTICLE $\quad$ ARAŞTIRMA MAKALESİ } & \\
\hline Title of Article & \multicolumn{2}{|c|}{$\begin{array}{c}\text { The Quality of Public Space Between the } \\
\text { City and the Coast } \\
\text { Examining the Frankfurt - Main Example }\end{array}$} & 2014 \\
\hline $\begin{array}{l}\text { Corresponding } \\
\text { Author }\end{array}$ & \multicolumn{2}{|c|}{$\begin{array}{l}\text { Ersin ABAY Yıldız Teknik Üniversitesi, Fen Bilimleri Enstitüsü, Mimari Tasarım Ana } \\
\text { Bilim Dalı, ersinabay@gmail.com }\end{array}$} & \\
\hline $\begin{array}{l}\text { Received Date } \\
\text { Accepted Date }\end{array}$ & \multicolumn{2}{|l|}{$\begin{array}{l}15.11 .2021 \\
08.12 .2021\end{array}$} & \\
\hline DOI Number & \multicolumn{2}{|c|}{$\underline{\text { https://doi.org/10.35674/kent.1024027 }}$} & \\
\hline Author / Authors & $\begin{array}{l}\text { Ersin ABAY } \\
\text { Ebru ERDÖNMEZ }\end{array}$ & $\begin{array}{l}\text { ORCID: 0000-0003-0813-7290 } \\
\text { ORCID: 0000-0001-8779-6037 }\end{array}$ & \\
\hline How to Cite & \multicolumn{2}{|c|}{$\begin{array}{l}\text { Abay, E., Erdönmez E. (2021). Kent ile Kıyı Arasında Kamusal Mekan Kalitesi } \\
\text { Frankfurt - Main Örneği, Kent Akademisi, Volume14, Issue 4, Pages, 1117-1136 }\end{array}$} & Urbar \\
\hline
\end{tabular}

\title{
Kent ile Kıyı Arasında Kamusal Mekan Kalitesinin Frankfurt - Main Örneği Üzerinden İncelenmesi
}

Ersin ABAY ${ }^{1}$

Ebru ERDÖNMEZ ${ }^{2}$

\begin{abstract}
:
In addition to ensuring the continuity of life in the natural environment, people also need some social and physical activities. In order to meet these needs, they should share their environment and be together with other people in a social interaction area. These common areas, which people need to use under the same conditions without considering a certain value or privilege, constitute public spaces. These urban areas have a number of social, physical, intellectual, perceptual and psychological effects on people. These effects determine the standards of life of the community and the quality of relationship that people establish with the place. Are the spaces pressed between the coast and the city comfortable enough? Is the relationship with water strong enough in these areas? In this study, as a public space, the quality of the space on the shores of the river was examined in the Frankfurt-Main River and the relationship between the city and public open spaces was evaluated. Consequently, in this study conducted in more than 1000 public spaces around the world, four basic quality criteria for a successful public space are; "access \& connections, use \& actions, comfort \& form, sociability" (Madden, 2001: 11-20). In this study, the historical period between Main river and Frankfurt city; the relationship between the coasts and the town, the use of public spaces on the coasts, the measurement of the quality of the spaces between the coasts and the city, the observation and literature research, the map and photograph and documentation method, Lynch's 'good city It has been examined through the criteria of vitality (a healthy environment), feeling (sense of place and identity), adaptation, access and control (Lynch K., 1984). By creating a scoreboard, a report on the study was created. The Bahnhofsviertel, which forms the rich historical texture of the city, and the public coastal areas between the Altstadt and the Sachsenhausen region, which forms the other side of the river, and Römerberg square and Dom square form the working boundaries. Based on the information, observations and literature research obtained as a result of this study, to make a public space quality assessment in the coastal areas between the Frankfurt and Main
\end{abstract}

\footnotetext{
${ }^{1}$ Y 1 ldız Technical University, Graduate School of Science and Engineering, ersinabay@gmail.com

${ }^{2}$ Y 1ldız Technical University, Faculty of Architecture, Department of Architecture, ebruerdonmez@yahoo.com
} 
river, to contribute to the development of coastal areas and to contribute to the improvement of the quality of the space on the coasts by making suggestions for future coastal use.

KEYWORDS: : Public Spaces, Public Riverside Spaces, Quality of Public Spaces, Frankfurt Main Riversides.

\section{ÖZ:}

İnsan, bulunduğu doğal çevre içerisinde yaşamının devamlılığını sağlamanın yanında bir takım sosyal ve fiziksel aktivitelere de ihtiyaç duymaktadır. Bu ihtiyaçlarını karşılayabilmek için bulunduğu çevreyi paylaşmalı ve diğer insanlar ile sosyal bir etkileşim alanı içerisinde birlikte olmalıdır. İnsanların belirli bir değer ya da ayrıcalık gözetmeksizin aynı şartlarda kullanım ihtiyacı duyduğu bu ortak alanlar kamusal alanları oluşturmaktadır. Bu kentsel alanların insanlar üzerinde sosyal, fiziksel, düşünsel, algısal ve psikolojik bir takım etkileri vardır. Bu etkiler toplumun yaşam kalitesini ve insanların mekan ile kurdukları ilişkinin kalitesi belirler. Kıyı ve kent arasında sıkışmış olan mekanlar yeterince konforlu mu? Bu alanlarda su ile kurulan iliş̧ki yeterince güçlü mü? Bu çalışmada bir kamusal alan olarak nehir kıyılarındaki mekan kalitesinin, Frankfurt - Main nehri özelinde incelenmesi ile kent ve kamusal açık alanlar arasındaki ilişki değerlendirilmiştir. Dünya genelinde 1000'den fazla kamusal alanda yapılan araştırmalar sonucu başarılı bir kamusal alan için dört temel kalite ölçütü; "erişim \& bağlantılar, kullanım \& eylemler, konfor \& biçim, sosyalleşebilirlik” olarak belirlenmiştir (Madden, 2001: 11-20). Bu çalışma ile sırasıyla nehir ile kent arasındaki tarihsel süreç, kıyıların kent ile kurduğu ilişki, kıyılarda kamusal alan kullanımları, kıyı ve kent arasındaki alanların mekan kalitesinin ölçülmesi, gözlem ve literatür araştırması, harita ve fotoğraf ile belgeleme yöntemi ile Lynch'in 'iyi bir şehir yapısı' için belirlediği yaşayan bir çevre, sezgisel olarak mekan ve kimlik, adaptasyon, erişim ve kontrol kriterleri üzerinden incelenmiştir (Lynch K., 1984). Bir puan tablosu oluşturarak, çalışma üzerine bir rapor oluşturulmuştur. Çalışma sınırlarını kentin zengin tarihi dokusunu oluşturan Bahnhofsviertel, Altstad ve nehrin karşı kıyısını oluşturan Sachsenhausen bölgesi arasındaki kamusal kıyı alanları ve Römerberg ile Dom Meydanları oluşturur. Bu çalışma sonucunda elde edilen bilgi, gözlem ve literatür araştırmasına dayanarak Frankfurt ve Main nehri arasındaki kıy alanlarında bir kamusal mekan kalitesi değerlendirmesi yapmak, kıyı alanlarının gelişimine katkı sağlamak ve geleceğe yönelik kıyı kullanım önerileri getirerek kıyılarda mekan kalitesinin iyileştirilmesine katkı vermek amaçlanmıştır.

ANAHTAR KELIMELER: Kamusal Mekan, Kamusal Kıyı Alanları, Mekan Kalitesi, Frankfurt Main Kıyıları,

\section{“Kent ile Kıyı Arasında Kamusal Mekan Kalitesinin Frankfurt - Main Örneği Üzerinden İncelenmesi"}

\section{GíRiş}

Kamusal alan, kamu sözcüğünden türemiş olan bir kavramdır. Kamu sözlükte ‘hep' ve ‘bütün' anlamlarına gelmektedir. Böylece kamusal alan da bütüne ait, herkese ait anlamında sözlükte yer edinmiştir. Bu tanımları ile birlikte kamusal alan toplumu ve tümünü ilgilendiren bir kavramdır. Kamusal alanlar insanların ortak bir şekilde kullanabildiği bütünleşme araçlarıdır. Bu alanlar kentlinin sosyo-kültürel paylaşımlarına olanak sağlayan, kişisel ve toplumsal gelişimi destekleyen, insan etkileşimlerini artıran mekanlardır. Kentler ve barındırdığı insanların, yer seçimlerine bakıldığında önemli bir bölümünün kıyı ve kıyıya yakın alanlarda konumlandıkları görülmektedir. Çok dar bir kıyı bandında, dünya nüfusunun \%38'ni barındıran ve 1990'da nüfusu 8 milyonu aşan mega kentlerin \%50'sinin kıyılarda konumlandığı, 2005 yılında bu oranın \% 70'e çıktığ izlenmektedir (Kılıç, Akın ve Koç, 2016). Bu öngörüler ile birlikte yakın gelecekte dünya nüfusunun büyük çoğunluğu kıyılara yerleşmeyi tercih edeceklerdir. Kıyı ile kent arasındaki doğal denge, nüfus ve orantısız artış ile birlikte kamusal alanların kullanımını da olumsuz etkileyecektir. Kentsel kıyı kalitesi, kamusal alan kullanıcısının da yaşam kalitesini doğrudan etkilemektedir. Frankfurt tarihi kent merkezi ile Main nehri kıyısı özelinde yapılan bu araştırma sonucu ortaya konulacak değerlendirme ile nehir kıyısı ile kentin kurduğu ilişki, kıyı alanlarının kamusal alan olarak mekan kalitesinin incelenmesi ve kıyı ile kent arasındaki doğal dengenin korunmasına yönelik bir araştırma çalışması yapılmıştır. İklim değiş̧ikliği ve suyun sebep olduğu felaketlerin artması ile günümüzde önemi iyice artan su ile ilişkinin daha değerli olduğu açıktır. Kıyı alanlarında geleceğe yönelik ve sürdürülebilir yöntemler 
incelenmiş, kıyıda çağdaş teknikler ve potansiyel tasarım araştırmaları ile kamusal açık mekanlarda mekan kalitesinin artırılması hedeflenmiştir.

\section{Kentsel Kıyı Kavramı}

Su yaşamsal kaynakların başında geldiği için, kentlerin oluşumunda ve konumunda önemli bir etkendir. Su kenarındaki yerleşim yerleri tarihsel süreç boyunca kara kentlerine göre daha çok tercih edilmiş ve suyun yaşamsal kaynağı sebebiyle daha hızlı gelişim göstermiştir. "Kıyı; deniz, doğal ve yapay göl ile akarsuların çevresini kuşatan, dalga, akıntı ve rüzgar işlevleri ile oluşturulan kumluk, çakıllık, taşlık, bataklık ve kayalık kara alanları ile saz gibi su bitkilerinin yetiştiği sığ su alanıdır" (Hakyemez, 1987). Kentsel kıyılar deniz, nehir, kanal ya da göl gibi herhangi bir su kaynağı kıyısında konumlanmış açık alanlardır. Bruttomesso, modern kentin yapısını belirleyen unsurlar arasında bir su kaynağının yer almasıyla karakterize edilen kıyıların yeni bir kategori oluşturmaya başladığını belirtmektedir. Kentsel kıyının çevresel ve kentsel özellikleri olarak su ile teması, su tarafından görünüşü, bu sınır ile kentin ilişkisi ve çeşitli aktivitelerin varlığını vurgulamaktadır (Bruttomesso, 2001). Kentsel kıyılar deniz ve okyanus kıyısı kentlerde farklı, koylarda göl veya durağan su birikintisi kıyı kentlerde farklı ve akarsu kıyısı kentlerde farklılıklar gösterir. Bu çalışma Frankfurt ve Main nehri özelinde incelendiği için kentsel kıyı kavramı nehir kıyılarında kent kıyısı açısından incelenmiştir. Nehir ve boğaz kıyılarında kentin iki kıyısı ele alınarak kentsel kıyı kavramından söz edilir. Akarsuyun bulunduğu yatağı ikiye ayırması ve iki su kıyısı yaratması diğer kıyı tiplerine göre daha fazla zenginlik ve olasılıklar yaratmaktadır. Diğer kıyı türlerinde ise kıyı lineer bir çizgi olarak tek taraflı ele alınır ve diğer çizgi su üzerinden oluşan ufuk çizgisidir.

\subsection{Kamusal Kıyı Alanları}

Kıyı mekanı; su ile karayı ayıran basit bir çizgi, bir sınırı değil, gerisinde tepeleri, sırtları, yamaçları, vadileri, düzlükleri ile doğal bir oluşumu, bu coğrafyada yer alan bir yerleşik mekân parçasını, önünde ise suyun üstünde ufuk çizgisi ile altında çukurlukları, düzlükleri ile üç boyutlu bir mekânı temsil eder. Bu nedenle kıyı en ve boy ile tanımlanan iki boyutlu bir alanın ötesinde su ve karanın özelliklerini yansıtan, içinde doğal ve yapay çevrenin şekillendiği ve şekillendirdiği bir yaşam mekânıdır (Kılıı̧, Akın ve Koç, 2016). Kamusal kıyı alanları mekansal nitelikleri ve kentlinin ortak kullanımına açık çevresel özellikleri ile kente değer katan kıyı alanlarıdır. Kıyı alanları kentlilerin günlük yaşamında sosyalleşme, dinlenme, çeşitli aktivite ve etkinlere imkan sağlama, spor yapma gibi faaliyetlere imkan sağlar. İnsanların bu alanlara stresten uzaklaşma, kent ve kentli ile etkileşim kurabilme sebebiyle de ihtiyacı vardır. Bu alanlardaki konfor ve mekan kalitesi, kullanıcı ile kıyı arasındaki ilişkinin de kalitesini ortaya koymaktadır. Bu sebeple kıyı mekanları açık mekan olgusunun yoğun olarak yaşanabildiği kentle uyum içindeki alanlardır. Kamusal alanlarda sosyalleşme ve herkes için adil kullanım gerekliliği beraberinde erişilebilirlik, çeşitlilik, farkındalık, bağlantı, kamusallık gibi alt başlıkları getirir. Başarılı sayılan kamusal açık mekânlar, kullanıcıların gereksinimlerine cevap verebilen, farklı sosyo-ekonomik, yaş ve cinsiyet gruplarına hitap edebilen ve kullanıcıların birbirleriyle, mekânla, kişisel hayatlarıyla ve tüm dünyayla güçlü bağlar kurmasına dolayısıyla yer duygusunun oluşmasına izin veren mekânlardır(Carr vd., 1992). Kıyılar ve kıyı mekanları da bu bağlamda kamusal açık mekanların bir parçası olup, kullanım ve konfor açısından geliştirilmesi ve incelenmesi önemlidir.

\subsection{Kamusal Alanlarda Mekan Kalitesi}

Kentsel mekan kalitesi yaşam kalitemizin de bir aynasıdır. 1960'lı yıllarda öne çıkan yaşam kalitesi kavramı; insanın yaşadığı ortamda ihtiyaç duyduğu her türlü fiziksel, sosyal, psikolojik ve ekonomik değerleri kapsamaktadır. Mekânın kalitesine yönelik araştırma yapan birçok teorisyen, incelemelerini algı ve bilgi süreçleri üzerine kurgulamışlardır. Çevrelerin, kentsel yapıların; algılanabilirliğine ve onların mekânsal belleğe kodlama rahatlığına göre o yere ait imajların değişiklik gösterebileceğini belirtmektedirler. Mekan kalitesinin ölçülmesi ve değerlendirilmesinde çeşitli teorisyenlerin farklı ölçüm parametreleri vardır. Genel olarak mekansal kalite araştırması algı ve bilgi süreçleri üzerinden incelenerek ölçülmeye çalışılmıştır. Algı ve bilgi süreçleri ile ilgilenen teoriler, genellikle etkenleri tanımlamak için, karmaşıklık, çeşitlilik, görsel dağılım, algısal zenginlik, düzen, okunabilirlik, açıklık ve uyumluluk gibi bir grup karşılaştırıcı kavram ve terim kullanılmıştır. Bir bütün olarak ele alındığında, iki temel boyut, sıklıkla karşılaştığımız karmaşıklık ve düzen kavramlarıdır (İnceoğlu ve Aytuğ, 2009). Rapoport, mekansal kaliteyi tasarımda öne çıkan, göze çarpan farklılıklar olarak ele almaktadır (Rapoport, 1982). Van der Voort, Van Wegen, mimarlıkta 
kaliteyi 4 ana başlıkta incelemektedir. Bunlar; işlevsel kalite, teknik kalite, estetik kalite ve ekonomik kalitedir (Voordt, 2005). Nasar, günlük aktivitelerinde insanların kentin kamusal mekânlarında bulunmalarını ve kentin şeklinin ve görünüşünün onu yaşayanları aynı zamanda da daha geniş halk kitlelerini tatmin etmesi gerekliliği üzerinde durmaktadır. Her durumda, önemli olan çevrenin kalitesinin izleyici tarafından algılanış şeklidir. Nasar tarafından kaliteler son derece genelleştirilmiş tercihler serisine dönüştürülmüştür. Mekansal kalitenin belirlenmesinde doğallık, bakım, açıklık ve tanımlanmış mekan, tarihsel önem ve düzen önemlidir (Nasar, 1998). Kentsel mekânlar, ihtiyaca cevap veren, demokratik ve anlamlı olmalıdır... İhtiyaca yanıt veren mekânlar, kullanıcıların ihtiyaçlarına hizmet edebilen ve bu şekilde tasarlanan mekânlardır. Kamusal mekânda en öncelikli ihtiyaçlar rahatlık, dinlenme, aktif/pasif katılım, keşfetme ve insani ihtiyaçlarıdır (Carr, Rivlin, Stone, Francis, 1992). Kevin Lynch ise 'Good City Form" adlı kitabında bir şehrin kalitesini ölçebilmek için canlılık, duygu, uygun olma, erişim ve kontrol parametrelerini ve her bir parametre için verimlilik ve adalet olmak üzere iki ana başlık belirlemiş̧ir (Lynch, 2009). Mekan kalitesinin ölçülmesinde gerekli görülen bu teorilerden kamusal kıyı alanları için uygun olan mekansal kalite parametreleri seçilerek Frankfurt ve Main nehri özelinde kent ve kıyı ilişkileri üzerine değerlendirme yapılmıştır.

\begin{tabular}{|c|c|c|c|}
\hline $\begin{array}{l}\text { Ișlevsel Kalite } \\
\text { Kullanım ve Eylemler }\end{array}$ & Estetik Kalite & Yapım Kalitesi & Bakım ve Hizmet Kalitesi \\
\hline $\begin{array}{l}\text { Ulaşilabilirlik } \\
\text { - Araç ve Ozel Araç } \\
\text { - Toplu Taşıma } \\
\text { - Yaya }\end{array}$ & $\begin{array}{l}\text { Düzen } \\
\text { - Uyumluluk } \\
\text { - Devamlıtlık } \\
\text { - Denge }\end{array}$ & $\begin{array}{l}\text { Detaylandirma } \\
\text { - Malzeme Birleşimleri } \\
\text { - Kent Mobilyalan }\end{array}$ & $\begin{array}{l}\text { Bakım - Onanm } \\
\text { - Yerel Yönetim } \\
\text { - Mülk Sahipleri } \\
\text { - Işletmeciler }\end{array}$ \\
\hline $\begin{array}{l}\text { Erișilebilirtik } \\
\text { - Mekan Içinde Rahat Hareket }\end{array}$ & $\begin{array}{l}\text { Kimlik } \\
\text { - Odak } \\
\text { - Birlik } \\
\text { - Karakter }\end{array}$ & $\begin{array}{l}\text { Malzeme } \\
\text { - Doğal } \\
\text { - Yapay }\end{array}$ & $\begin{array}{l}\text { Kamu ve Ozel Hizmetler } \\
\text { - Temizlik } \\
\text { - Illetişim }\end{array}$ \\
\hline $\begin{array}{l}\text { Ceşitlitik } \\
\text { - Sosyal Otabitme } \\
\text { - Düzenlemelerin Yetertiliği } \\
\text { - Aktivite Yeterlitiği }\end{array}$ & $\begin{array}{l}\text { Etki-Çekim } \\
\text { - Olçek } \\
\text { - Uygunluk } \\
\text { - Cantılık } \\
\end{array}$ & $\begin{array}{l}\text { Issçilik } \\
\text { - Işçilik Kalitesi }\end{array}$ & \\
\hline $\begin{array}{l}\text { Esneklik } \\
\text { - Değissen Șartlara Uyum Sağlama } \\
\text { - Değișken, Çok Ișlevli }\end{array}$ & & $\begin{array}{l}\text { Dayanıklılık - Sağlamlık } \\
\text { - Malzeme Seçimi ve Ozellikler }\end{array}$ & \\
\hline $\begin{array}{l}\text { Güventik } \\
\text { - Bireysel Güventik }\end{array}$ & & & \\
\hline $\begin{array}{l}\text { Mekansal Bütüntük } \\
\text { - Kapalılık }\end{array}$ & & & \\
\hline $\begin{array}{l}\text { Konfor } \\
\text { - Yürüme, Oturma, Görüș, } \\
\text { Gürültü, Aydınlatma }\end{array}$ & & & \\
\hline Sürdürülebilirlik & & & \\
\hline
\end{tabular}

Şekil 1. Mekansal Kalite Göstergeleri (İnceoğlu 2007 ve Voordt 2005) / Spatial Quality Parameters

Kalite kavramıyla ilgili araştırmalarda kavramın çok boyutlu ve katmanlı olmasından dolayı mimarlık alanında da bu kavramla yapılacak araştırmalarda mekân veya yere sadece işlevsel özellikleri ile değil, o yere özgü onu tanımlayan ya da onu anlamlı kılan birçok özelliğiyle beraber ele alınması gerekliliği doğmaktadır(İnceoğlu, M., Aytuğ, A. 2009). Yürüyüş yapmak, ayakta durmak, oturmak, görmek, duymak ve konuşmak için gerekli nitelikleri ve ortam koşullarını tanımlamıştır (Gehl J., 2001) Jan Gehl'in kamusal mekânda mekânsal kalite standartlarını güvenlik, konfor ve hoşnutluk olarak üç başlık altında toplayan Birgitte Svarre bu kriterler sağlandığında kamusal mekânda kalitenin artacağını belirtmiştir. 


\section{2. Çalışma Alanı - Frankfurt Main Örneği}

Frankfurt Main nehri üzerinde kurulmuş ve ilk yerleşim izleri buzul çağına kadar dayanan, bir dönem Roma imparatorluğuna da hizmet etmiş ve günümüzde Almanya'nın Hessen Eyaleti içerisinde yer alan 750.000 nüfuslu bir kıyı kentidir. Kıyının öncelikle bir tarafında gelişen şehir, nüfus ve nehir üzerindeki ticaret ağı genişledikçe nehrin iki tarafında da gelişim göstermeye başlamıştır.

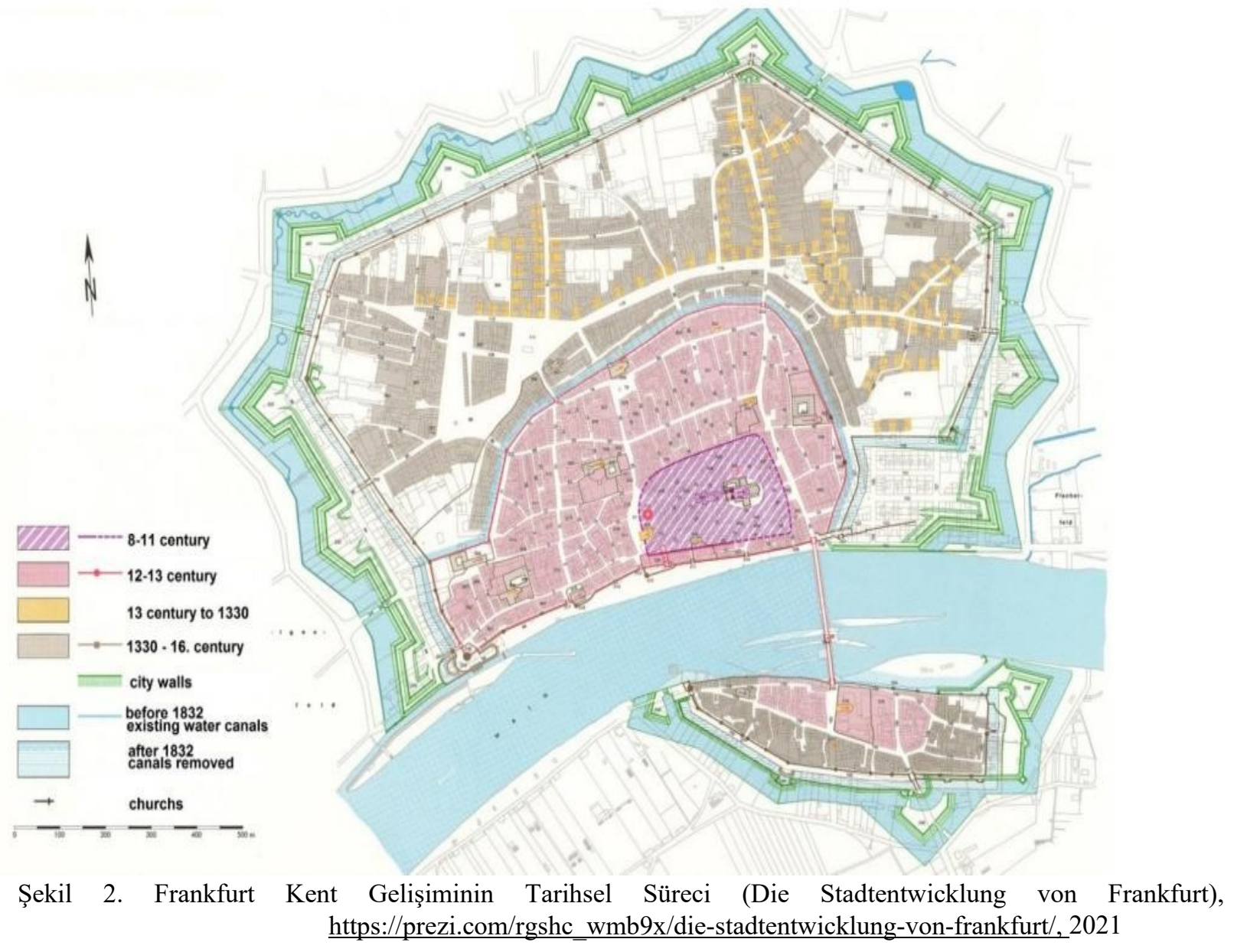

Frankfurt ilk yerleşim izlerinden de görülebileceği üzere nehir kıyısındaki orta çağ yerleşim izlerinden zamanla dışarıya doğru güvenlik surları ile birlikte gelişerek kentin sınırlarını genişletmiştir. Kentin merkezi Altstadt (eski şehir) hala kentin ana merkezini oluşturur. Bu bölümde Roma dönemine ait bulgular ve yerleşim izleri kent merkezi içinde müzede sergilenmektedir. İkinci Dünya Savaş’ı sonrası kentin büyük bölümü köprüleri ve korunmuş yapıları yüksek oranda yok edilmiştir. Savaş sonrası kentin yenilenmesi yazı, belge, fotoğraf, çizimler gibi bir çok girdi ile restorasyon ve rekonstrüksiyon sürecine girmiştir. Dış surların ve kulelerin bulunduğu kenti çevreleyen koruma kanallarının izinde kent merkezinin sınırlarını çevreleyen parklar bulunur. Bugün kent sınırları ulaşım ağının gelişmesiyle de iyice genişlemiş̧ir ve Main nehri üzerinden şehrin kuzey ve güneyine doğru büyümeye devam etmektedir. Mevcut yapılaşma lekesi üzerinden de anlaşılabileceği üzere insanlar yoğunlukla nehrin kıyılarında yerleşmeyi tercih etmiştir. Şehir Main nehrinin üçte bir oranında ikiye ayırdığı ve kuzey yoğunlukta bir yerleşimin hakim olduğu planlamadadır. Ancak kentin kuzeye doğru yerleşimin artması sadece ulaşım ağlarının gelişmesi sebebi ile değil aynı zamanda orta çağ köylerinin izlerinin hala korunuyor olmasındandır. Praunheim, Ginnheim, Eckenheim, Heddernheim gibi sonu 'heim' olarak biten bu isimler Roma imparatorluğundan kalma köyü anlamına gelen yerleşim birimlerine aittir. Güneyde ise Sachsenhausen ve Niederrad gibi iki büyük yerleşimin ardından Frankfurt Havalimanını da içine alan Almanya'nın en büyük şehir ormanı olan Frankfurt Kent Ormanı ile şehrin sinırları belirlenmiş olur. Günümüzde İngiltere'nin de Avrupa 
Birliği’nden ayrılmasının ardından Frankfurt AB için finans merkezinin kalbi pozisyonuna gelmiştir. Aynı zamanda Almanya'nın beşinci büyük kenti olan şehir, Almanya'nın en çok yüksek yapısı olan ve uluslararası kimliği ile en çok göçmen yaşayan kentlerinden birisidir. Avrupa'da satın alma gücünün en yüksek olduğu ve dünyanın en yaşanabilir kentleri arasında ilk on şehir içerisinde yer almaktadır.

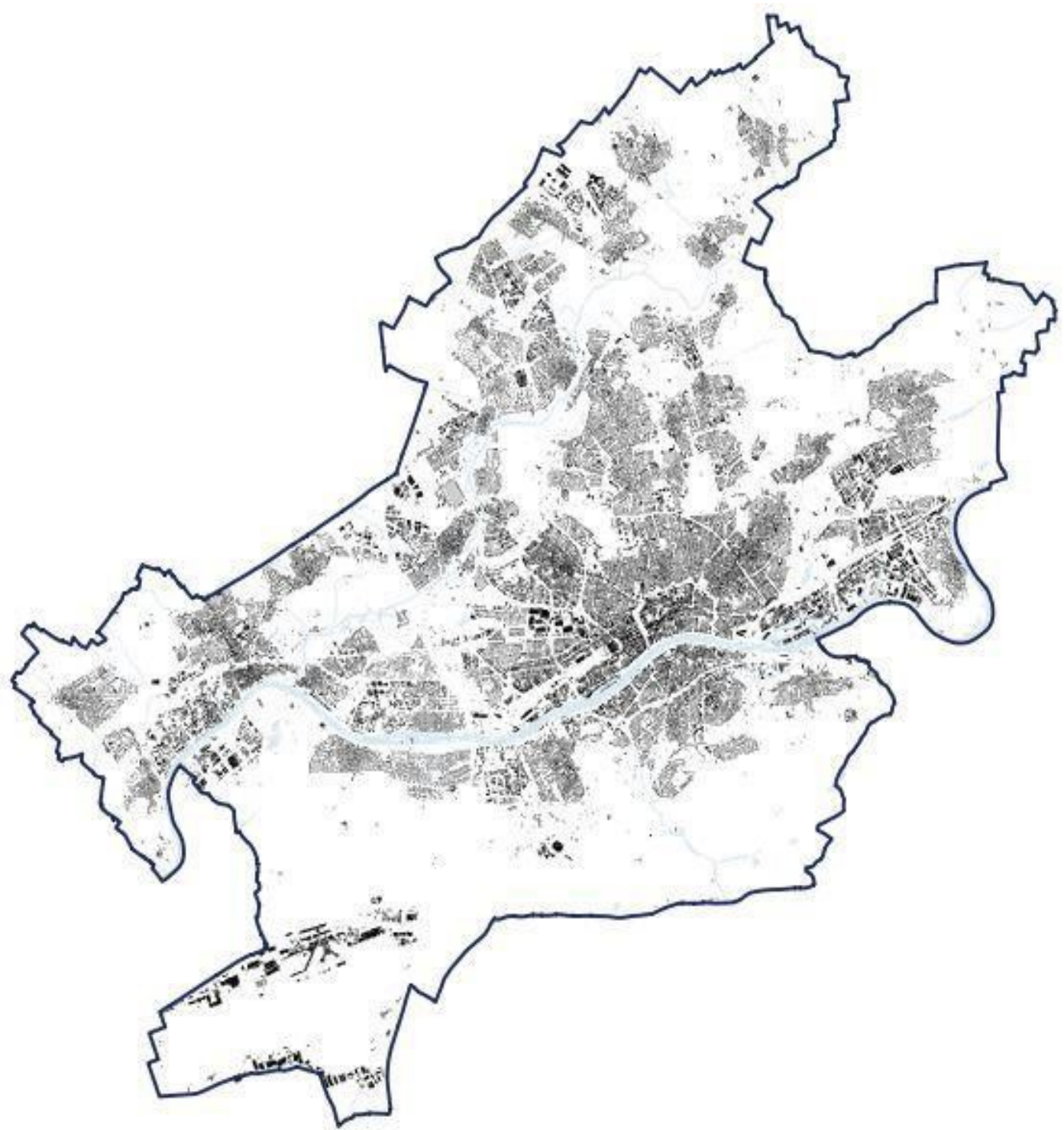

Şekil 3: Frankfurt 2021, Stadtplannungsamt Kentin Yapılaşma Haritası (geoportal.frankfurt.de), https://geoportal.frankfurt.de/karte

\subsection{Fiziksel Özellikler Bakımından Kent ve Nehir İlişsisi}

Frankfurt kent merkezinin nehir ve çevresi ile kurduğu ilişkiyi öncelikle kentin fiziksel özellikleri bakımından incelersek, yeşil alanlar, kent imgeleri, sokaklar, caddeler ve bağlantılar, erişilebilirlik ve kamusallık kavramları öne çıkmaktadır. Aynı şekilde algısal olarak kontrol, güvenlik ve hissiyat gibi duyusal etmenler de fiziksel çevrede önemli rol oynamaktadır. Yerleşimin morfolojik dokusu bakımından kent merkezi incelendiğinde, kentin ilk yerleşim izlerinden kalan katmanlı bir şekilde genişleyen izlerini görürüz. Organik ve dar sokakları ile iç kısımlarına yerleştirilmiş avlular 
kentin Innenstadt ve Altstad bölgesini oluşturur. Bu alan aynı zamanda sur izleri ve koruma kanallarının çevrelediği alandır. Günümüzde kentin dış surlarının izini koruyan bir yeşil park hattı ile bu sınırlar vurgulanır. Meydanlar, parklar ve kamusal alan kullanımı hem turistik hem de kentli kullanımı açısından yoğundur. Meydanlar, sokaklar, eski şehir surlarını içinde barındıran alanlar, nehir kıyılarına ulaşımı sağlayan bağlantı yolları ve nehrin iki yakasındaki geniş açıklık ile köprüler kamusal ve yarı kamusal alanları oluşturmaktadır. Kentsel kıyılar, kent ile suyun kurduğu ilişki açısından kıyıda faydalı bir çevre oluşturma beklentisi yaratırlar. Kıyıdaki geniş açıklık nehrin taşma kontrolü sebebiyle önemlidir. Bu olumsuz gibi görünen durum esnek tasarım ve yere bağlı olmama durumu getirdiğinden aynı zamanda kıyıda tasarım, pozitif yönde gelişim kararları açısından büyük potansiyel barındırır. Kıyıda sadece insanların değil aynı zamanda hayvanların da bir doğal yaşam alanı mevcuttur. Tam da bu noktada doğal yaşam ile dengeli kamusal alan tasarımları, her canlının kamusal alan üzerinde eşitlik, erişebilirlik, konfor gibi haklara sahip olması önemlidir. Breen ve Rigby kıyıdaki endüstrileşme sonrası projelerin başarısını suya yaklaşmak yerine suyun yakınında yaşamak, çalışmak ve eğlenmek olarak tanımlarken, projenin kıyının gerçek bir parçası olup olmadığını önemsemektedir. Ayrıca kıyıları kentin yaşam kalitesini artıracak alanlar olarak değerlendirmektedir (Breen ve Rigby, 1996). Kıyı ile birlikte bir kent imajı yaratması açısından Frankfurt diğer kıyı kentlerinden silüeti ile ayrışmaktadır. Avrupa'nın en çok gökdelen yapısının bir arada olduğu kentlerden biri olan kent nehir, kıyıdaki hareketlilik, kıyıdaki yapılaşma ve tarihi kent merkezinin arkasında kalan modern yapılar ve onları da arasından yükselen gökdelenler ile birlikte kent için özel bir imge oluşturmaktadır.

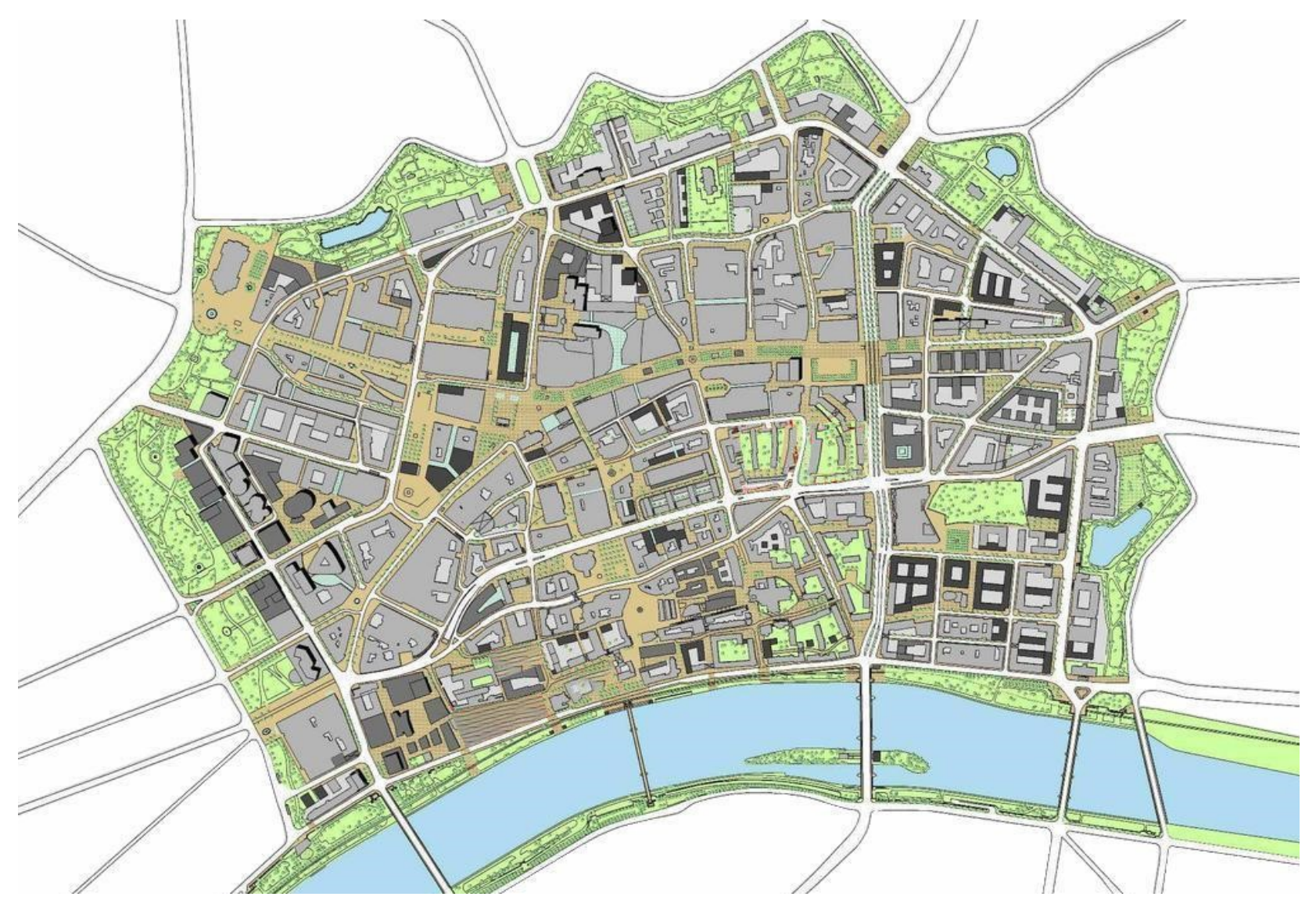

Şekil 4: Frankfurt Innenstadt-Altstadt ve Main Nehri Morfolojik Yapısı (Stadtentwicklung), https://docplayer.org/48368610-Stadtentwicklung-frankfurt-am-main-die-leitprojekte-martinhunscherstadtplanungsamt-frankfurt-am-main.html

Nehir kıyısına açılan dar sokaklar ile meydanlar ve ana arteri oluşturan caddeler bağlanmıştır. Karşı kıyı ile kent merkezini bağlayan beş adet köprü bulunmaktadır. Nehir kıyısı ile kent merkezi arasında taşma ve sel güvenliği 
açısından belli noktalar yükseklik farkları görülür. Ayrıca küçük bir ada olarak nehrin ortasında kalan bir rekreasyon alanı da bulunmaktadır. Bu alan içerisinde morfolojik dokunun kentin geri kalanından kolayca ayrılmaktadır. Nehir kıyısında ise ticaret limanı olarak kullanılan endüstriyel araçlar ile kıyıdan kent içlerine uzanan demiryolları kıyı boyunca sergilenmektedir. Kentin dokusu, tarihi, sokakları ve meydanları ile çevrili olan bu merkez kentin kendi kimliğini öne çıkarır. Mekan kalitesinin ölçülmesi ile ilgili teoriler üzerinden öne çıkan başlıklar ile bu alanda, işaret ögeleri, bağlantılar, donatılar, meydan ve sokaklar ile erişim ve kontrol ilişkileri incelenmiştir.

\section{2 İşaret Ögeleri ve Odak Noktaları}

Kevin Lynch 'Image of the City' adlı kitabında bir kentin okunmasını üç ana başlık üzerinden değerlendirmektedir. Bunlar kent kimliği, yapı ve anlamdır. Bu bileşenlerin oluşturduğu kent imajı kentin bir özetini belirlemiş olur. İşaret öğesi, zihinde mekanın imgesinin oluşmasına, mekan içinde yön bulmaya, mekanı tarif etmeye, mekanı hatırlamaya ve mekanı öğrenmeye hizmet eder. Tüm bu başlıklar toparlandığında okunabilir mekan özelliklerine sahip oluruz (Köseoğlu, 2012). Innenstadt içerisindeki en belirgin işaret ögesi öncelikle kent merkezini oluşturan Römerberg Meydanı'dır. Savaş sonrası neredeyse tamamı yıkılan kent merkezi, yenilenerek tarihi atmosfere uygun bir ortam yaratılmaya çalışılmışıtır. San Nicola kilisesi ve Eski Belediye binası ile meydan kent içindeki en önemli işaret öğesi olmaktadır. Römerberg adı 'zum Römer' evinden yani dönemin belediye binasından gelmektedir. Bu meydan orta çağın başlarında nehrin daha geniş ve akıntının daha yoğun olduğu dönemde su ile daha yakın bir ilişki kurmaktadır. Römerberg meydanı yoğunlukla Gotik ve kısmen Barok tarzı yapılardan oluşmuştur. Ancak 1944'teki ağır hava saldırısı sonucu büyük oranda yapı tahrip edilmiştir. Bugünün meydanı ise arşiv ve araştırmalar sonucu 1950'lerden 1980 yıllarına kadar restorasyon ve rekonstrüksiyon çalışmaları ile elde edilmiştir. İç kısımlarda ise mimari yarışmalar ve lokal araştırmalar ile rekonstrüksiyon çalışmaları günümüze kadar devamlılığını sürdürmektedir. Meydanın güney tarafinda tarihi kent merkezinin kilisesi olan Nikolai kilisesi bulunmaktadır. Ayrıca meydanın tam ortasında 1543 yılından beri 'Adalet Çeşmesi' bulunmaktadır.

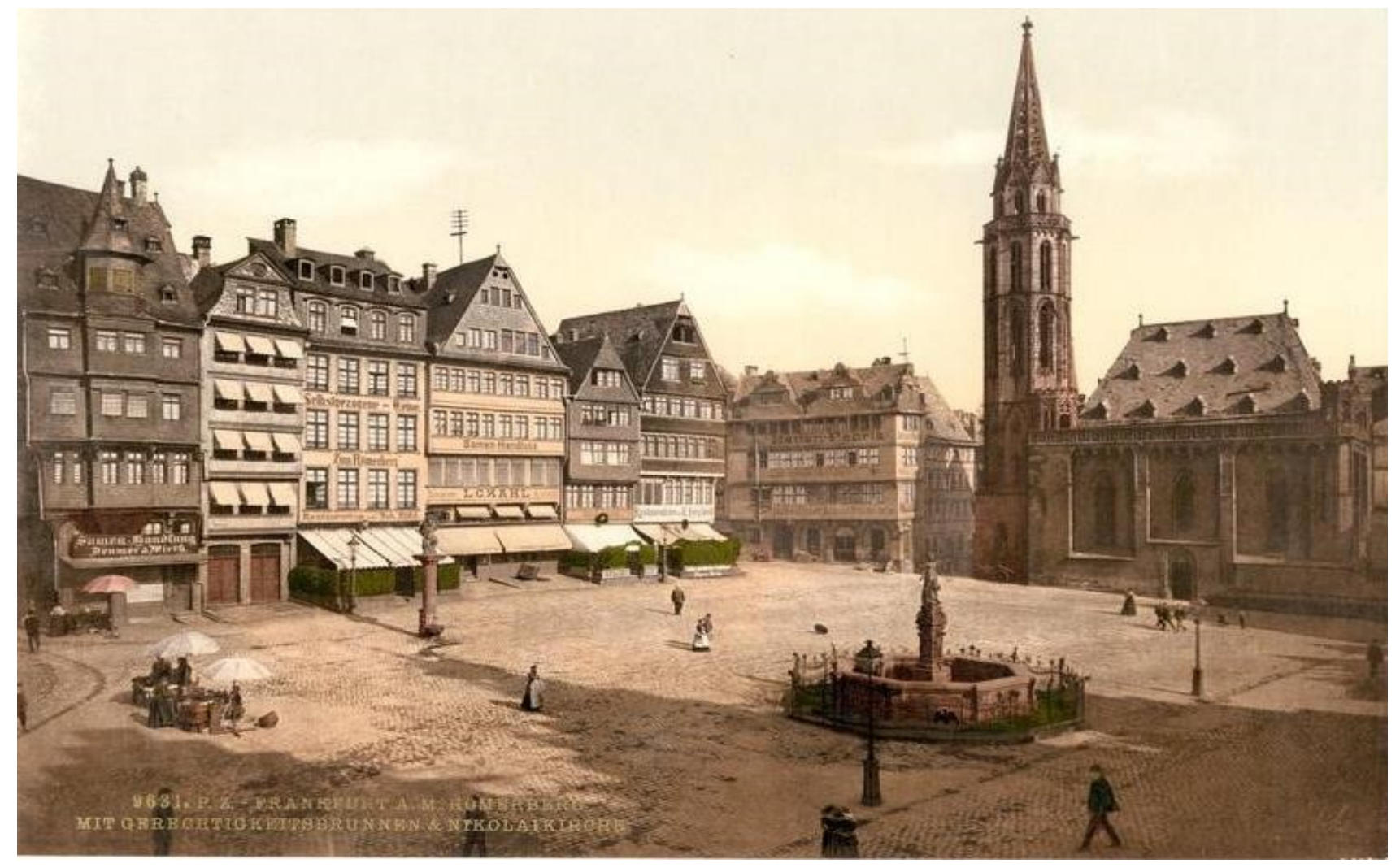

Şekil 5. 1890-1900 arası Nikolai Kilisesi ve Adalet Çeşmesi

(https://commons.wikimedia.org/wiki/File:Romerberg_and_Nicholas_Church,_Frankfort on_Main 


\section{(i.e._Frankfurt_am_Main),_Germany-LCCN2002713664.jpg}

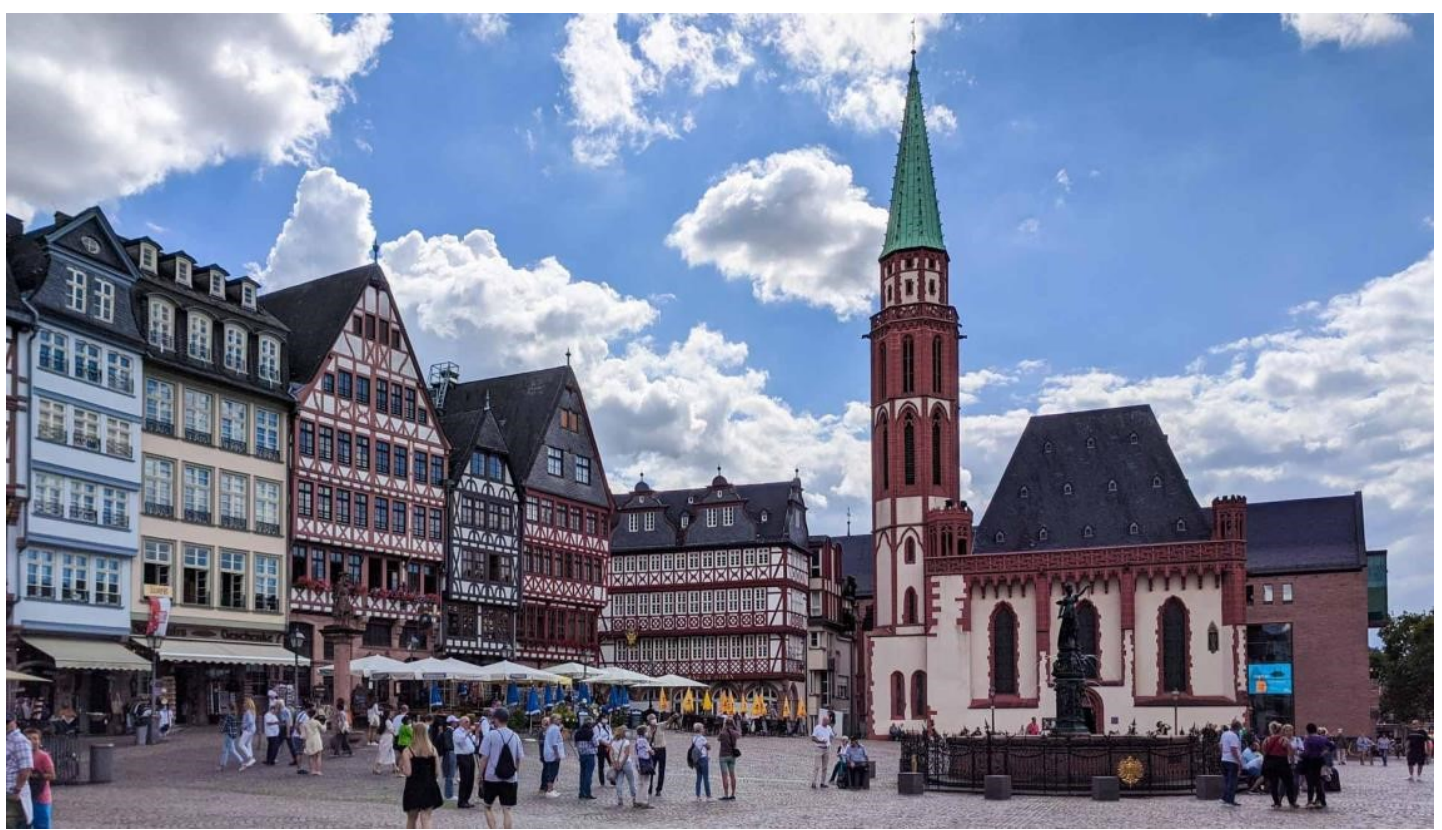

Şekil 6. Römerberg Meydanı, Rekontrüksiyon Çalışmaları Sonucu (https://jordanrec.com/archives/57519

Altstad'ın adeta kentin içindeki yerini tanımlayan, kent meydanının şehrin bir çok yerinden algılanmasını sağlayan bir diğer odak ise Saint Bartholomew Frankfurt Katedrali'dir. Özgün taş dokusu ve mimarisi ile öne çıkmaktadır. 14. ve 15.yy'da kendisinden daha eski olan bir kilisenin üzerine inşa edilmiştir. Ardından İmparatorluk seçimlerinde, taç giyme törenlerinde kullanılmıştır. Siyasetteki rolünün artması ile kilise İmparatorluk tarihinin en önemli yapılarından biri haline gelmiştir. Savaş sonrası kentin büyük bölümü ile birlikte kilise de içindeki yangın ile büyük zarar görmüştür. 1950’lerde yeniden inşa edilerek 95mt yüksekliği ile kentin önemli simgelerinden biri olmuştur.

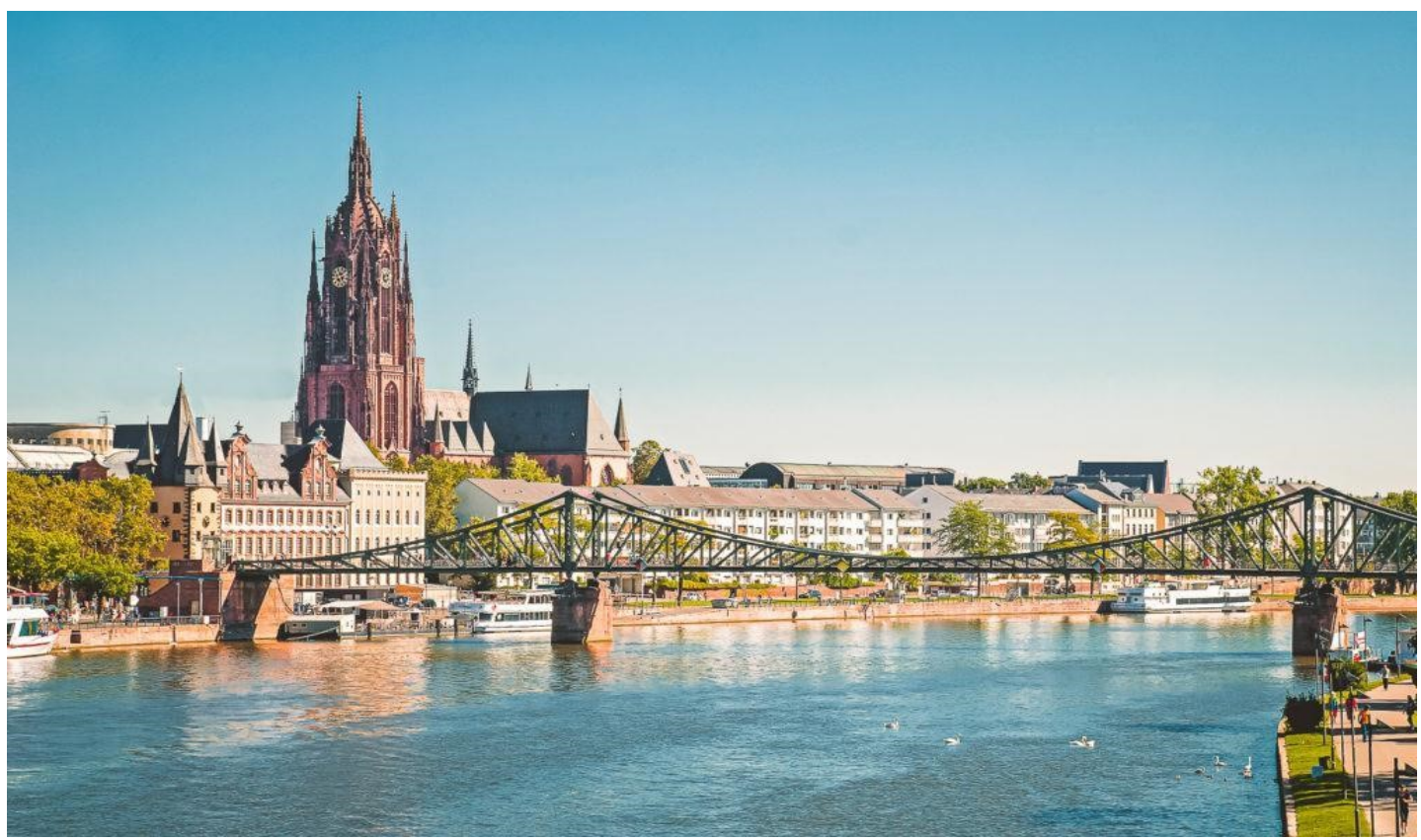


Şekil 7. Frankfurt Katedrali ve Eiserner Köprüsü (viel-unterwegs)

https://vielunterwegs.de/reiseziele/deutschland/frankfurt-am-main/sehenswuerdigkeiten/ Eiserner Köprüsü kenti karşı kıyıya (Sachsenhausen) bağlayan yaya köprüsü 1868 de inşa edilmiştir. Ancak savaşın son günlerinde Nazi güçleri tarafından yıkılmıştır. Savaş sonrası kısa zamanda tekrar inşa edilen köprü güçlendirme çalışmaları ile günümüze ulaşabilmiştir.

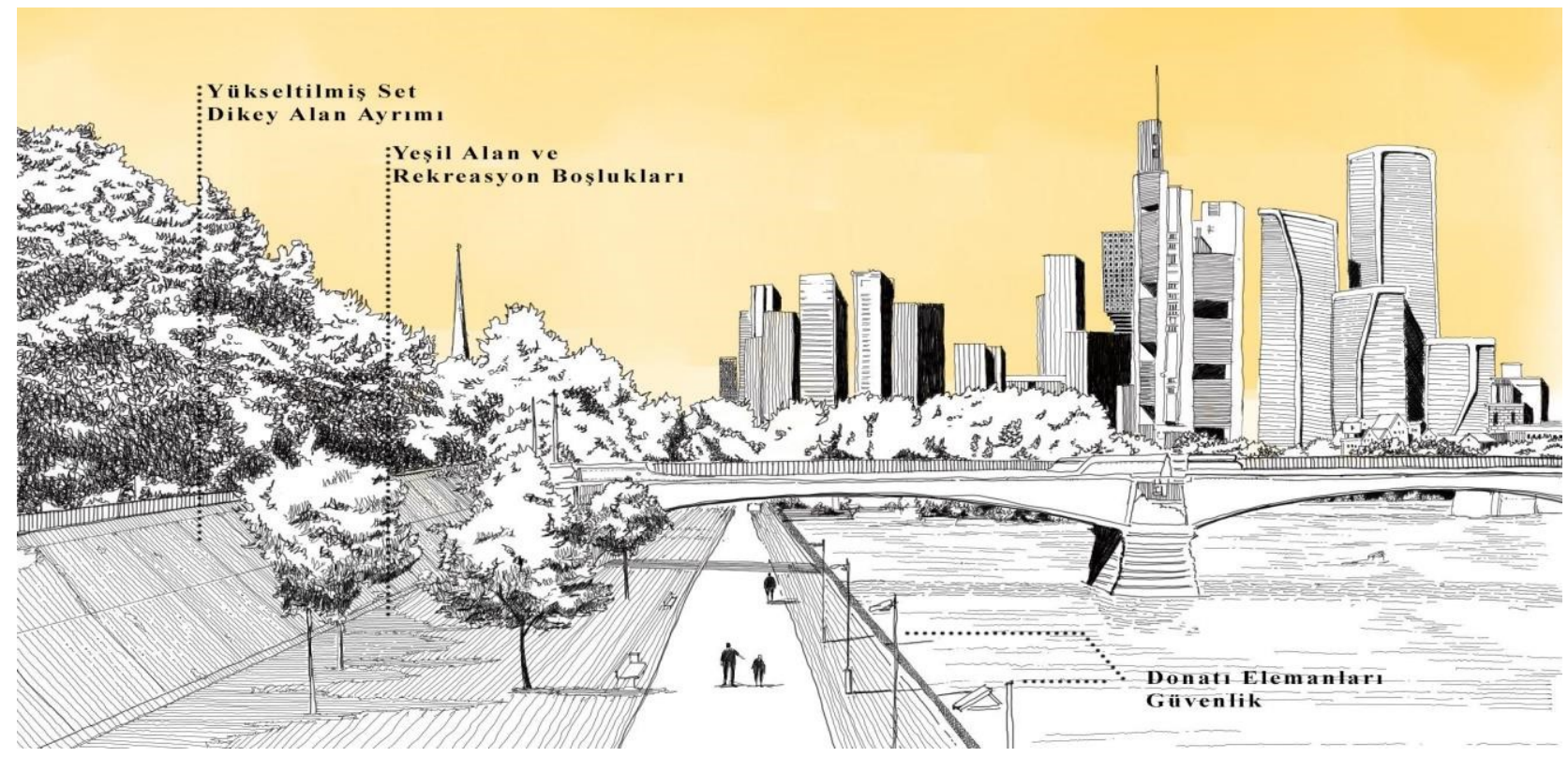

Şekil 8. Frankfurt Katedrali ve Eisener Köprüsü (Yazar)

Kentin su üzerinden algısını güçlendiren, kıyı ile kent arasındaki ilişkiyi kurabilmeyi sağlayan bir ögedir. Kentin kıyı silüetini ise gelişmekte olan finans merkezi konumundaki Gökdelenler Bölgesi etkilemektedir. Goethe Meydanı'nı çevreleyen ve batıya doğru sayısı artan gökdelenler sadece kent için değil Almanya geneli için de Frankfurt kimliğini oluşturan bir imaj yaratmaktadır.

\section{Bağlantılar, Kıyılar ve Meydanlar}

Kent içinde eylem alanları arasındaki dolaşım, ilişki akslarıdır. Kuşkusuz, bu aksların tümü değil, birey üzerinde etki bırakmış olanlardır. Bağlantılar, sokaklar, caddeler olabileceği gibi, kanal, köprü, vb. ulaşım, iletişim ağları da olabilir. (Lynch, 1960) Römerberg meydanı ve Dom meydanı iki ana cadde ile birbirine sirkülasyon edecek şekilde bağlanmaktadır. Römerberg meydanı tarihi süreç içerisinde büyük bir Pazar alanı olarak da hizmet etmiş ve nehir ile Pazar alanı arasında güçlü bir bağlantı oluşturmuştur. Eisener köprüsü ile bu ticari alan kentin karşı kıyısına da ulaşmış ve kıyılar arası güçlü bir bağ kurulmuştur. 


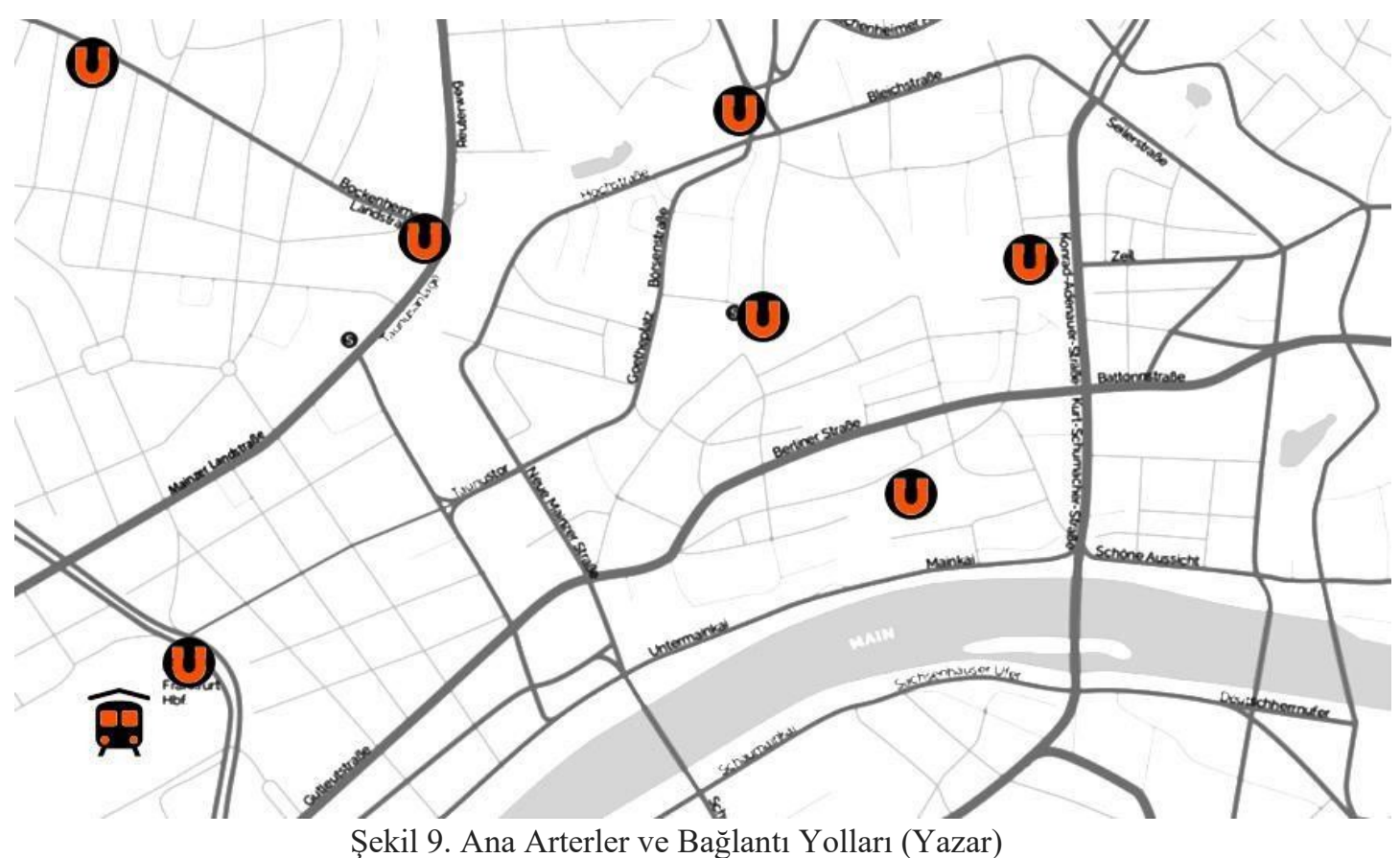

Tarihi köprü ile 17yy. da Main Nehri üzerinde ticari bir kontrol ve kıyılar arası önemli bir bağlantı vardır. Kent merkezini, içindeki meydanları ve karşı kıyıdaki Sachsenhausen bölgesini biribirine bağlayan Eisener Köprüsü ve Altebrücke kentin en dinamik yaşam alanını oluşturmaktadır. Tarihi kentin karşı kıyısı ise günümüzde müzeler, tarih, mimarlık ve güzel sanatlar ile zenginleşmiş bir yerleşime sahiptir. Güney kıyısından kentin silüeti ve gün batımı daha etkileyici bir görsel yarattığından dolayı insanlar bu kıyıda vakit geçirmeyi daha çok tercih etmektedir. Eisener Köprüsü üzerinden sadece yaya bağlantısı yapılmaktadır. Eski köprü üzerinden ise araç ve bisiklet yolları ile kıyı bağlantısı sağlanmaktadır. Eski köprü olarak bilinmesine rağmen tarihsel süreç içerisinde yaklaşık 15 kez yıkılıp tekrar yapılmıştır. Son olarak savaş sonrası iki tonoz ve revak kaybeden köprü 1965 'te çelik bir sistem ile yenilenerek günümüze ulaşmıştır.

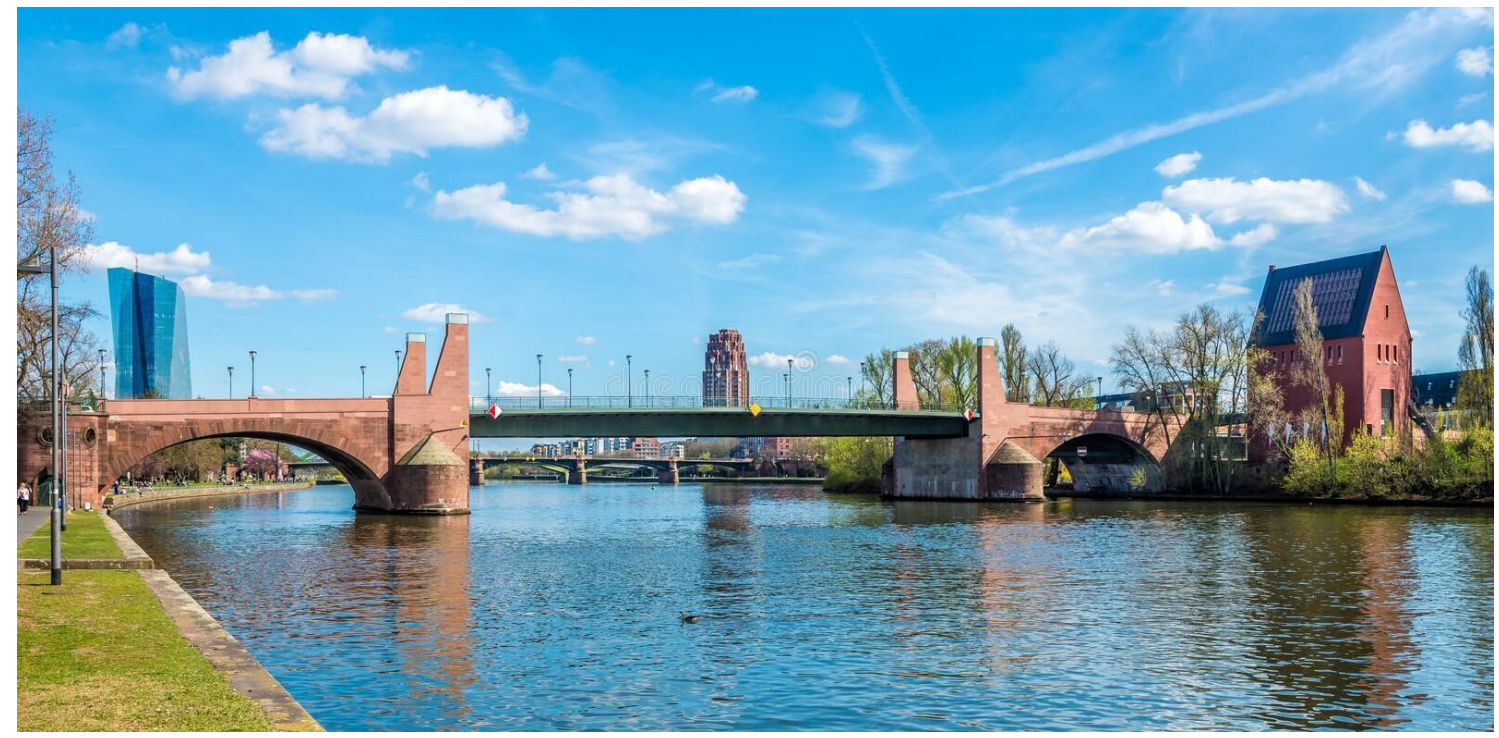

Şekil 10. Frankfurt Tarihi Köprü ve Maininsel (Dreamstime Frankfurt), https://www.dreamstime.com/photosimages/bridge-over-main-river-frankfurt-germany.html 


\section{Donatılar}

Kentsel donatı elemanları, tanımlayıcı, belirleyici, yönlendirici ve bilgilendirici elemanlardır. Donatı elemanları için kentin kimliği ile ilişkilenebilecek bir kültürel boyuttan ve ölçek, renk, malzeme, form vb. gibi özellikleri içeren fiziksel bir boyuttan söz edilmektedir. Kamusal açık alanlar donatı elemanları ile desteklenmelidir. Kamusal alanlarda imaj ve konfor açısından kente uyum sağlayacak ürünler, kent mobilyaları, spor alanları ve etkinlik alanları, yeterli sayıda çöp ve aydınlatma ünitesi, zemin malzemesi, bisikletli, yaya ve özürlü için gerekli bilgilendirme, pano, uyarı levhası vb. ilgili donatı ürünleri kamusal alanın mekansal kalitesi için önemlidir.

\section{Kıyı Şeridinde Tasarımın Önemi}

Neredeyse tüm şehirlerimiz ve kültürel alanlarımız nehir kenaralarında gelişmiş ve evrilmiş̧ir. Nehirlerin getirdiği dinamik akışkanlık kentler arası gezilebilirliği ve sosyal ilişkileri artırmıştır. Nehir kıyısı ve insan elinin şekillendirdiği kıyı mekanları, kıyı kültürümüzün temelini oluşturmuştur. Ancak bir nehir bir kent için çok değerli bir unsur olurken aynı zamanda çok tehlikeli ve yıkıcı bir unsur da olabilir. Nehir kıyısı yerleşimlerin en önemli özelliği bu değişkenliğe karşı esneklik sağlayabiliyor olmasıdır. Bu korunaklı ve aynı zamanda kamusal alana katkı sağlayacak olan tasarım önerileri ile günümüzde bir çok nehir kıyısı kent için daha güvenli ve daha faydalı mekanlar üretmek mümkündür. Günümüzde nehirlerin bir çoğu kentle uyum sağlayacak şekilde dönüştürülmüştür, ancak iklim değişikliği ve dünya üzerindeki su dengesinin değişkenliği ile sel felaketlerindeki artış ve yetersiz önlemler ile kıyılar yeniden sorgulanmaya başlamıştır. Bu konu tek başına sadece bir problemi çözmek üzerine değil aynı zamanda yeni aktivite alanlarının ve kıyı tasarımlarının potansiyelini tekrar ele almak için bir fırsat olarak görülmelidir. Öncelikle suyun temizliği, arıtma, atık, doğal yaşamın korunması ile başlaması gereken kıyı tasarım kararları alınmalıdır. Su yollarını çok işlevli olarak şekillendirmeye, insanlar, sudan faydalanan canlılar ve etrafındaki tüm canlı florası için çağdaş teknikler ve yaklaşım ile nehir kıyılarını detaylıca ele almak gereklidir.

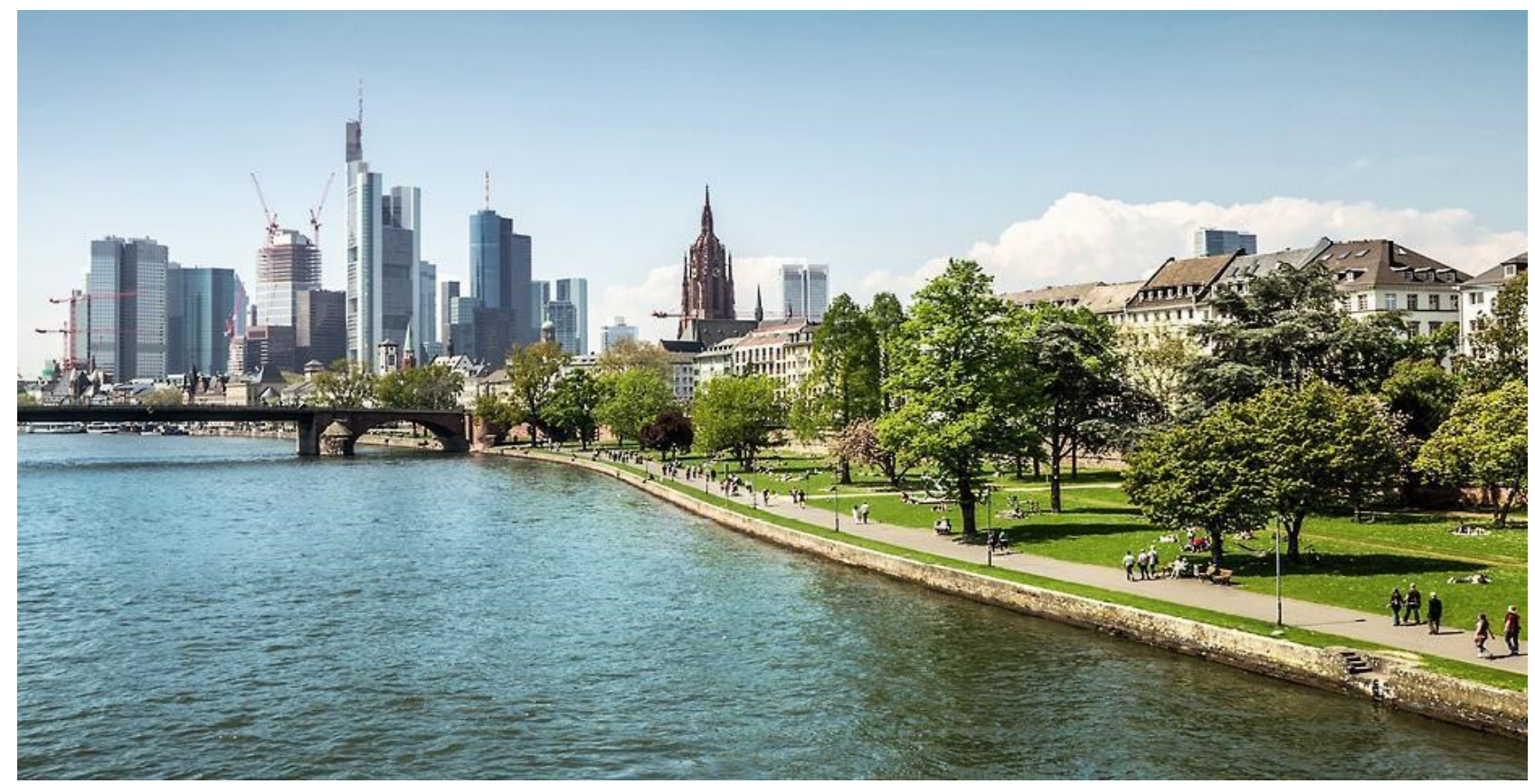

Şekil 11. Frankfurt Main Nehir Kıyısı ve Parklar (greencity), https://www.frankfurtgreencity.de/en/berichteuebersicht/status-and-trends/climate-and-open-spaces/renewing-frankfurts-energy/ 


\section{Kamusal Açık Alanlarda Mekan Kalitesinin Değerlendirilmesi}

Mekan kalitesinin değerlendirilmesi Römerberg Meydanı üzerinden işaret ögelerinin bağlantıları ile tarihi kent merkezinin kıyıları sınırları içerisinde incelenmiştir. Bu bağlamda erişilebilirlik, donatılar, dokular ve yeşil alanlar, aktivite imkanları ve kent imajı üzerinden değerlendirme yapılmıştır.

Öncelikle meydan Dom Meydanı ve Pauls Meydanı'nın bağlantısında kaldığı için güçlü bir bağlantı noktasıdır. Güneyde ise öncelikle nehir kıyısını merkeze daha sonra da Eisener Köprüsü ile Sachsenhausen Bölgesi'ne doğrudan bağlandığı için kentin en dinamik bağlantı aksı üzerinde bulunmaktadır. Meydana ulaşım, metro, tramvay, otobüs ve özel araç ile çok seçenekli ve yeterlidir. Römerberg Meydanı eğimli bir meydandır, zemin dokusu karo taş üzerine yapılmış olup giriş ve çıkışlarda herhangi bir set engelli ulaşımını önlemez. Ancak görme engelli biri için zeminde bir yönlendirici veya farklı zemin dokusu barındırmadığı için bu anlamda yetersizdir. Ayrıca meydan giriş-çıkışlarında ve içerisinde bir bilgilendirme panosu bulunmamaktadır, zaman geçirme ve meydanı deneyimleme açısından oturma üniteleri sadece Adalet Çeşmesi etrafinda yer almaktadır. Bu durum çeşmenin okunabilirliğini ve önemini azaltırken aynı zamanda büyüklüğüne oranla meydan için çok az sayıdadır.

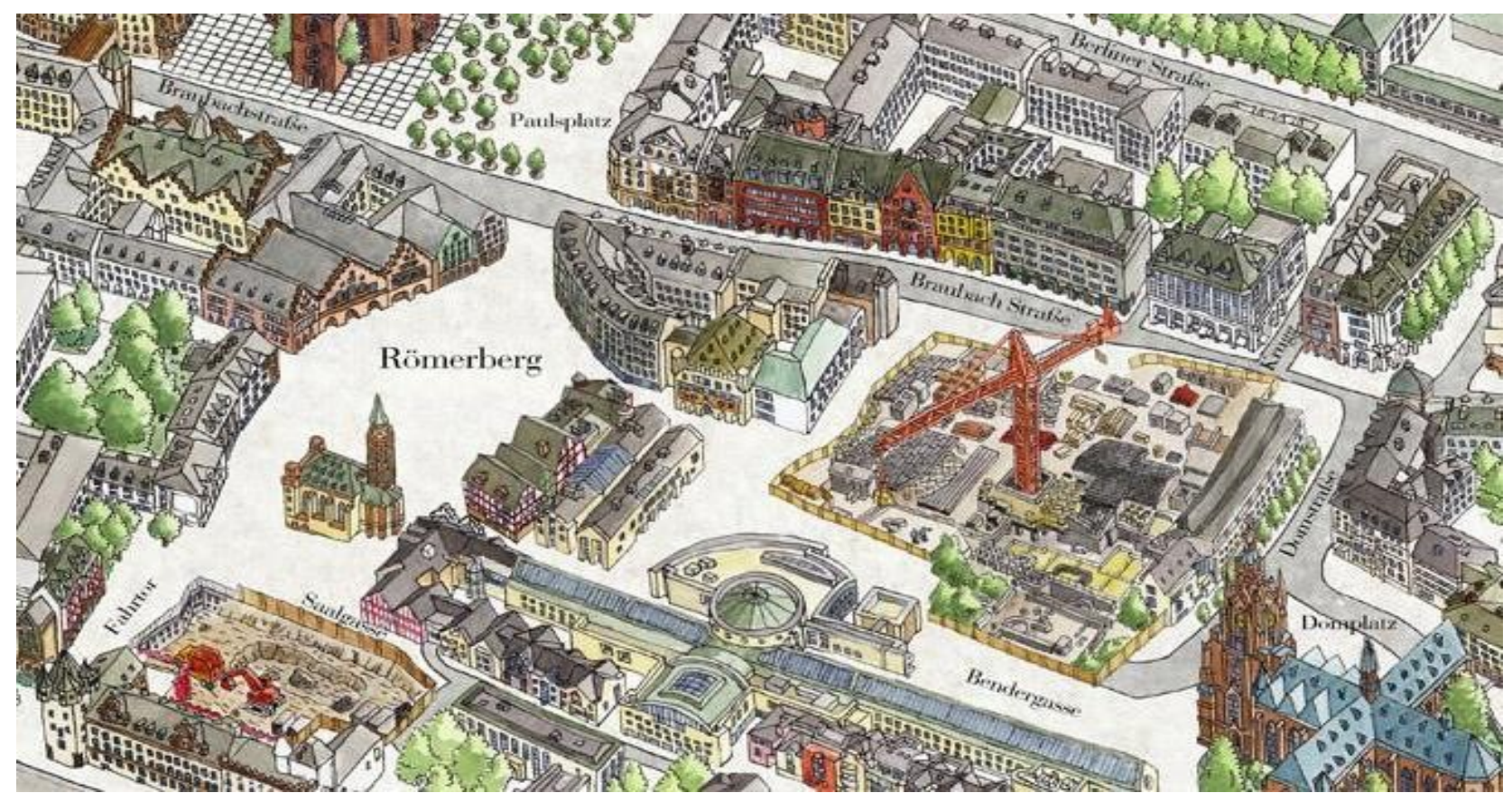

Şekil 12. Römerberg Meydanı, Dom Meydanı ve Pauls Meydanı (Borgarmynd Frankfurt), http://cargocollective.com/borgarmynd/Frankfurt-3d-Map

Aydınlatma üniteleri gece meydanın algılanması için yeterli sayıdadır. Çöp ve temizlik için gerekli olan donatılar aydınlatma ünitelerinin yakınında desteklenmektedir. Meydan törenler, festivaller ve yılbaşı için modüler sahne ve donatılarla organize edilebilir özelliktedir. Meydan bir rekonstrüksiyon olarak ayakta durduğu için imaj olarak yeterlidir ancak duyusal olarak tarihi bir meydan deneyimi hissini vermemektedir. Frankfurt için önemli bir turistik durak ve bağlantılar arası kesişim noktası olması sebebiyle meydan kullanımı günün erken saatlerinden itibaren aktif ve hareketlilik içindedir. 


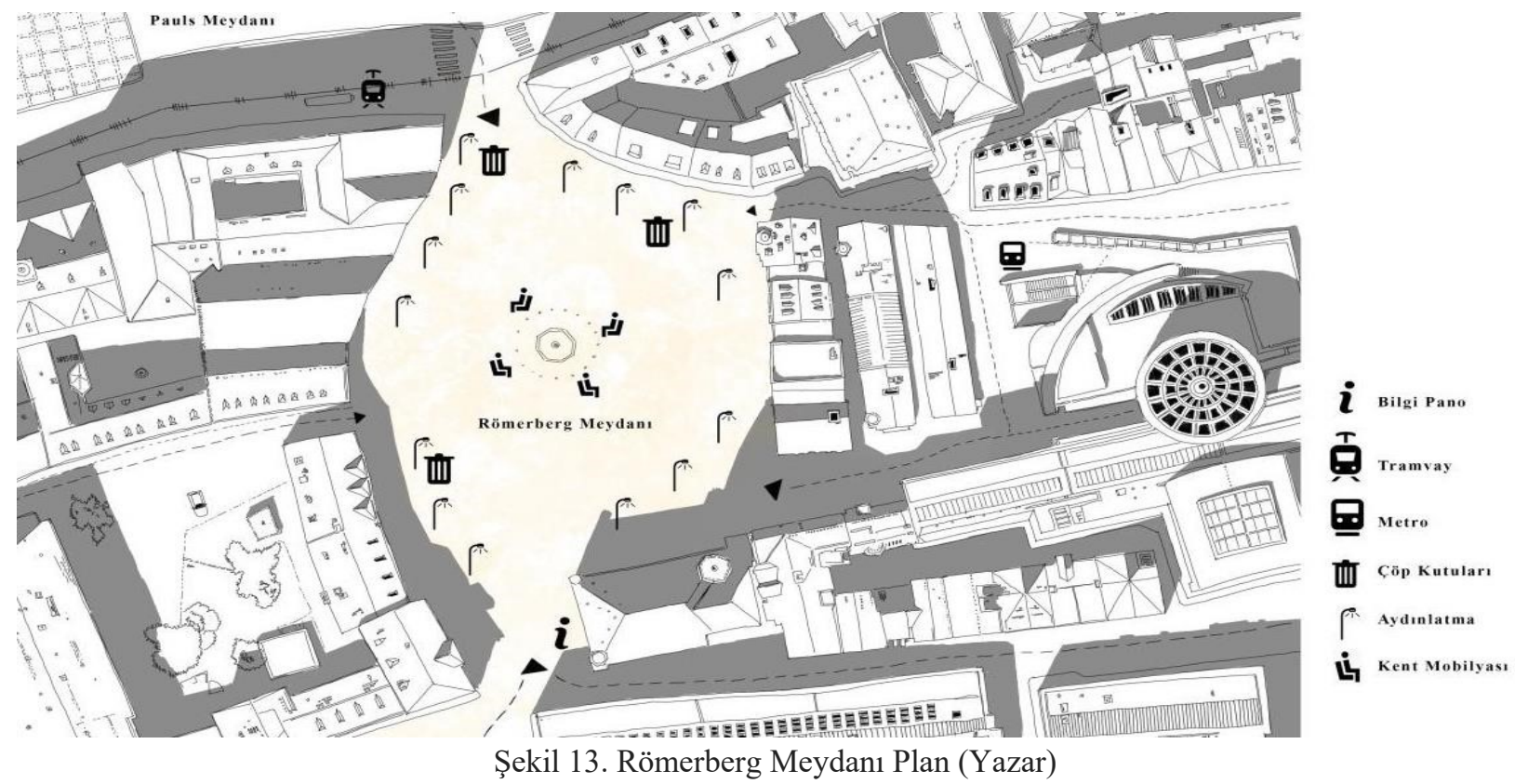

Dom Meydanı ise Nehir kıyısı ve Römerberg meydanı arasındaki üçüncü önemli odaktır. Römerberg meydanı Nikolai kilisesi ile birlikte kent merkezi simgesini taşırken Kaiser Dom yüksekliği ve Barok tarzı mimarisi ile öne çıkar. Kentin bir çok noktasından algılanabilir ve ciddi bir çekim noktası oluşturur. T planlı yapısı gereği çevresinde dört küçük meydan yaratır. Nehir kıyısından doğrudan algılanabilir pozisyonda olup engelli erişimine bir set barındırmamaktadır. Aydınlatma ve bilgilendirme konusunda Römerberg meydanına göre daha zayıftır. Dinlenme ve zaman geçirme açısından daha az kent mobilyası içerir. Dom Meydanı giriş kapısı yönünde meydan olarak adlandırılmıştır ancak meydanın sınırları bakımından algısı zordur. Güneydoğu tarafı otopark olarak kullanılmaktadır. Gün içerisinde dinamik ve turistik yoğunluk içerir. Ancak kilisenin kapalı olduğu süreçte dar sokaklardan ulaşımı ve çevresinde pek fazla aktivite alanı olmaması sebebiyle konforlu bir alan olduğu söylenemez.
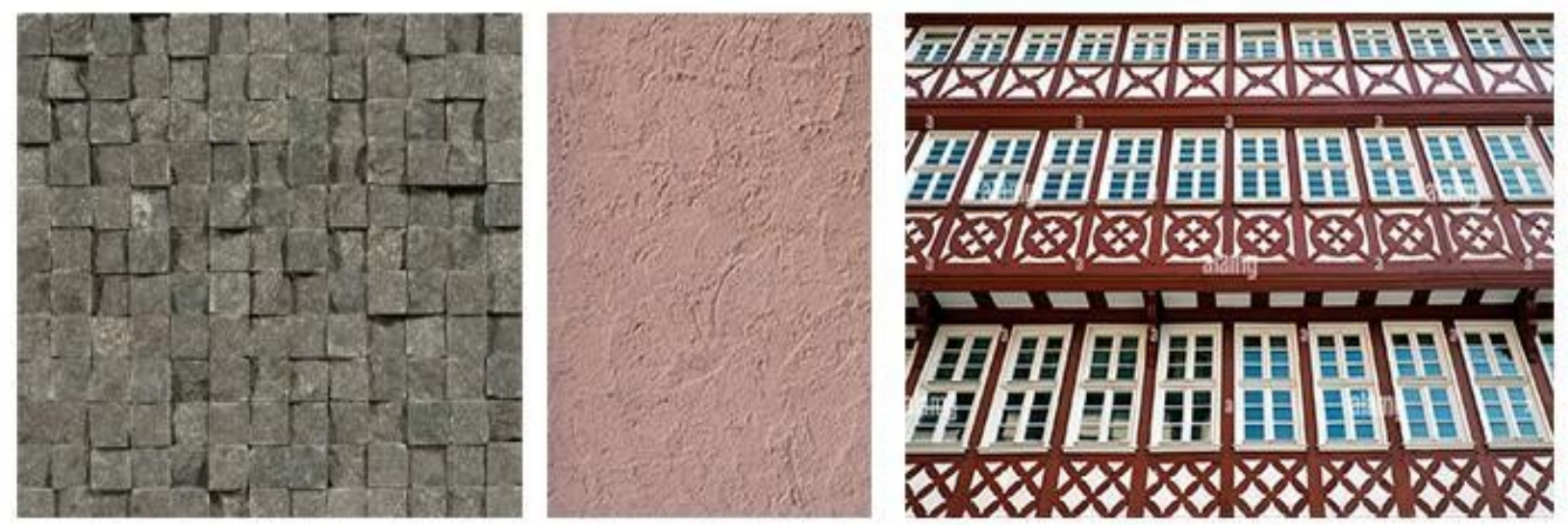

Şekil 14. Römerberg Doku İzleri (Yazar)

Eiserner Köprüsü kentin yaya köprüsüdür. Bu köprü ile Sachsenhausen bölgesi Römerberg meydanına bağlanırken, Eski Köprü (Altebrücke) ile kent Dom Meydanına bağlanmaktadır. Sachsenhausen bölgesi nüfusa oranla daha genç ve aktif bir hayatın olduğu bir bölgedir. Kent; Innenstad, Hauptwache, Goethe Meydanı ve çevresinde hem alışveriş hem de iş hayatını barındırır. Bu sebeple bir çok insan kentin diğer kıyısında yaşamayı tercih ederken iş için bu iki önemli bağlantıyı kullanır. Köprü; engelli asansörü, merdivenler ve bisiklet taşımak için rampalar ile gereklilikleri 
sağlamaktadır. Kıyılarda dinlenme oturma, vakit geçirme için gerekli kent mobilyaları, aydınlatma ve kafe, kiosk gibi destekleyici unsurlar bulunur. Kıyıda yol, kaldırım, yeşil bant ve yürüme yolu şeklinde bir kesit kullanım alanı mevcutur. Nehir ile yol arasında ortalam 5 m'lik bir yükseklik farkı ile kentin ulaşım ve dinleme alanları ayrılmıştır. Kıyı ile üst kot arasında mesafe oluşan alanlarda kıyı boyunca merdivenler ve rampalar mevcuttur.

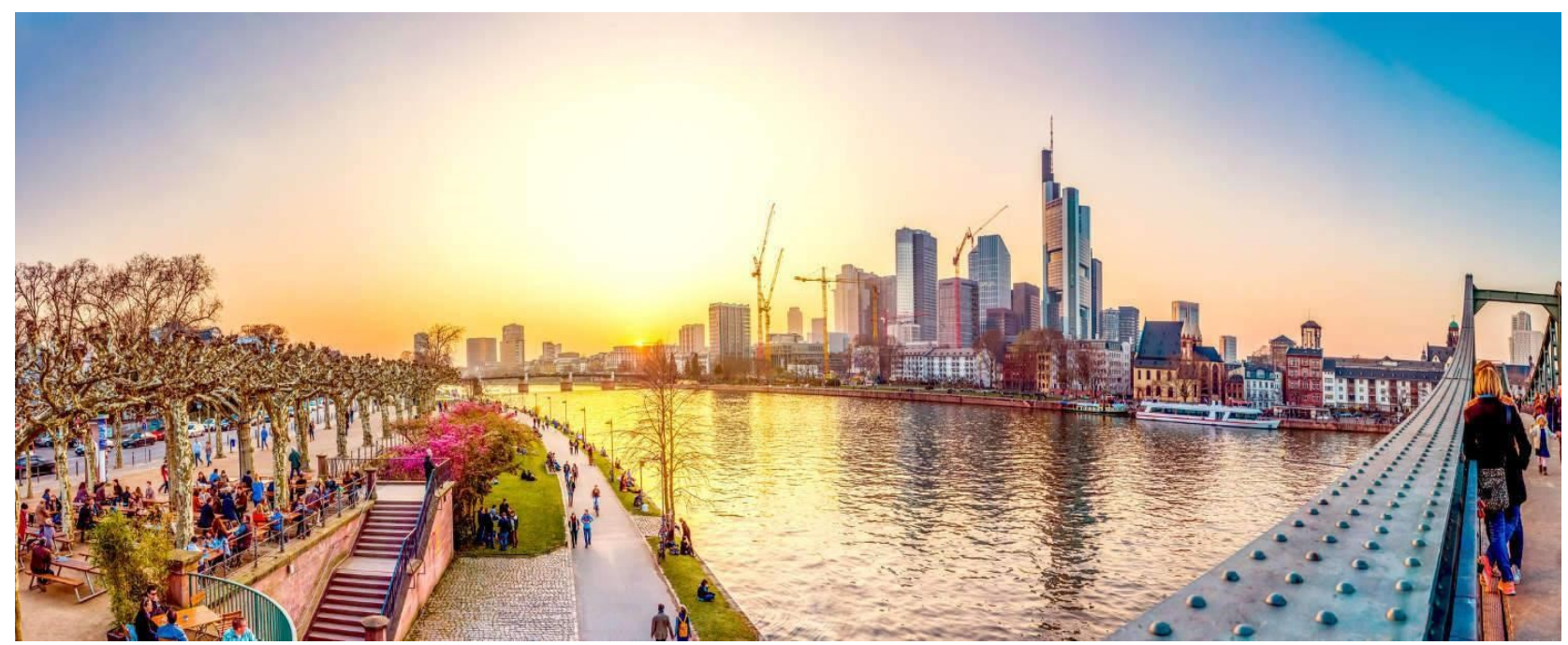

Şekil 15. Eiserner Steg / Sachsenhausen Tarafından Kente Bakış, https://www.hotel.de/blog/frankfurtsachsenhausen/

Köprüler ve kıyılar gün içerisinde özellikle iş çıkış saatlerinde en yoğun zamanını yaşar, su kıyısı başlıca bir çekim alanı oluşturur. Ayrıca kent imajı da hem köprü üzerinden hem de kıyllardan insanların dinlenirken, spor yaparken, kitap okurken, sosyal aktiviteler için önemlidir. Kıyı boyunca aydınlatma üniteleri ve çöp kutuları yeterlidir. Ayrıca kıyının genişlediği alanlarda, masa tenisi, piknik masası, çocuk oyun üniteleri gibi çekim noktası yaratacak aktivite alanları yeterli sayıda bulunmaktadır. Altstadt kıyısında ise nehir turları için botlar, performans sanatçıları için alanlar, kiosklar ve kafeler kıyııı aktif hale getirmektedir. Kıyı boyunca yeşil alan hakimiyeti kentin sınırlarına kadar devam etmektedir. Kıyıdaki yeşil alanlar hem hayvanlar için hem de insanlar için korunaklı, konforlu ve dinlendirici bir imkan sunmaktadır.

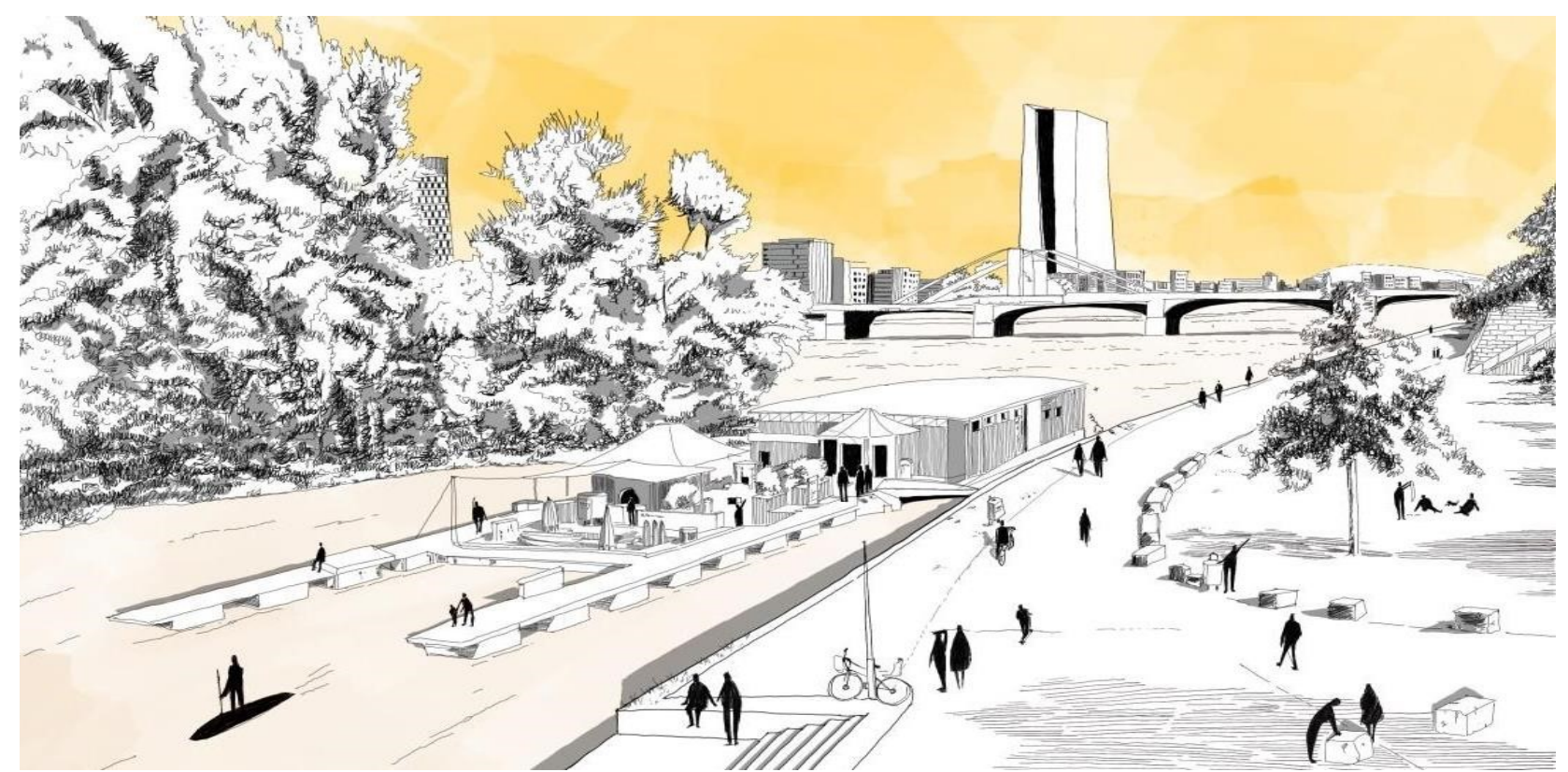

Şekil 16. Maininsel ve Eski Köprü ile Nehir Kıyısı (Yazar) 
Eski köprü üzerinde daha çok araç bağlantısı mevcuttur. Sachsenhausen ile Dom meydanını birbirine bağlayan eski köprü yaya yoluna ve bisiklet yolu ulaşımına da imkan verir. Ayrıca köprü üzerindeki dinlenme cepleri köprü üzerinden kente bakış, dinlenme ve vakit geçirme noktası olarak köprüyü sadece geçiş alanı değil duraklama alanı olarak da işlevlendirir. Köprünün ayakları altındaki Main adası üzerindeki Portikos isimli yapı ile çeşitli sergi, davet, kutlama gibi etkinliklere olanak sağlar. Ancak yarı kamusal bir alan olarak Maininsel bölgesine giriş belirli günler ve saatlerde mümkündür. Ayrıca köprünün Sachsenhausen kıyısından itibaren Eiserner Köprüsüne kadar olan alanda yan yana sıralanmış Müzeler Caddesi bulunur. Kıyılardaki donatı alanlarında kent mobilyası, aydınlatma, çöp kutuları, yönlendirme levhaları yeterlidir. Engelli erişimi için rampalar ve yönlendiriciler mevcuttur. Köprü üzerinde ve kıyı şeritlerinde görme engelliler için zemin dokusunda değişiklikler ile yol, bisiklet yolu, yaya yolu ayrımları yapılmıştır.

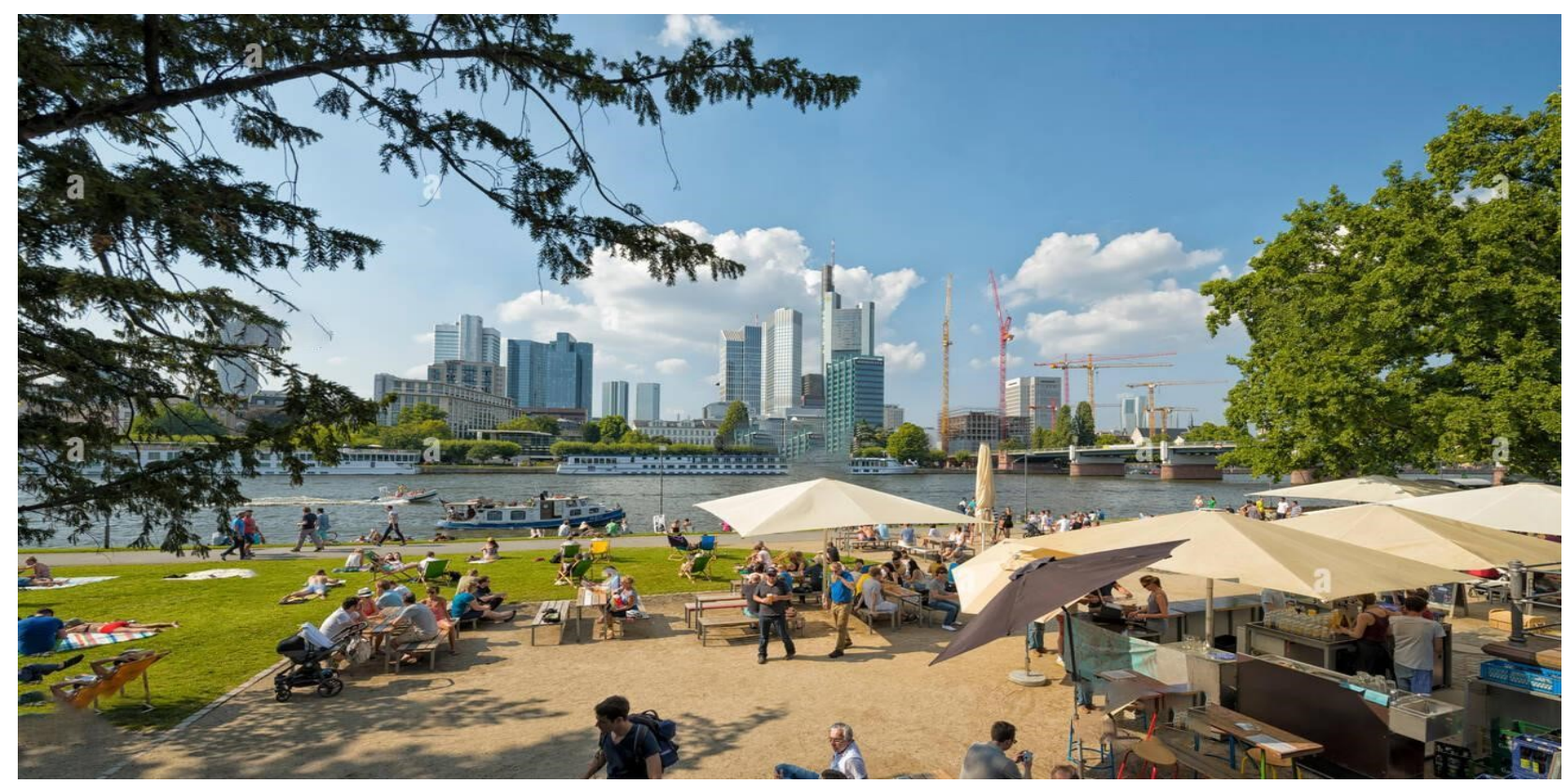

Şekil 17. Main Nehri Açık Mekanlar, https://www.alamyimages.fr/photo-image-allemagne-hesse-frankfurt-ammain-main-cafe-a-frankfurt-promenade-riverside-85978020.html

\section{Değerlendirme Sonucu}

Frankfurt, geçmişi ve kent yapısı ile her zaman nehir ile iç içe bir yaşamı benimsemiştir. Orta çağdan itibaren çevresinde yerleşim izleri taşıyan bir çok kültüre ev sahipliği yapmış olan zengin bir kenttir. Kıyı kullanımı da aynı şekilde orta çağdan itibaren başlayarak günümüze kadar gelmiş ve bir çok kez kıyı yeniden tasarlanmıştır. Kıyılar tarih boyunca seçkin mekânlar olmuşlardır. Kara parçası ile su arasında bir ara mekân oluşturarak eşik görevi gören kıyılar aynı zamanda toplumların da ihtiyacı olmuştur (Çelik K., 2015). Kent merkezi küçük bir alandan genişleyerek güçlenmiştir. $\mathrm{Bu}$ büyümenin ve gelişimin en önemli sebeplerinden biri de kentin nehir ile kurduğu ilişki olmuştur. Kıyı tasarımları bireylerin su ile iletişiminde etkin rol oynamaktadır. Kullanıcıların suya erişimleri, su ile ilişkisi tasarımın tanıdığı imkanlarla sağlanmaktadır. Dokunma, seyretme veya işitme eylemleri su ile iletişim kurmanın duyusal yöntemleridir. Bu bağlamda kentin en önemli akslarını Sachsenhausen Bölgesi, Römerberg Meydanı, Dom Meydanı ve nehir bağlantıları oluşturur. Araştırma kapsamında kent meydanları ve nehri de içine alacak şekilde incelenen bu alanda kıyıların önemi, kente kattıkları değer, kent merkezini nasıl destekledikleri, kamusal alan olarak mekanların kalitesinin durumu üzerine bir puanlama yöntemi ile yapılmıştır. 


\begin{tabular}{|c|c|c|c|c|c|c|c|c|c|c|c|c|c|c|c|c|}
\hline \multirow{2}{*}{$\begin{array}{c}\text { Mekansal Kalite Bileşenleri } \\
\text { Değerler }\end{array}$} & \multicolumn{4}{|c|}{ Römerberg Mey } & \multicolumn{4}{|c|}{ Dom Meydanı } & \multicolumn{4}{|c|}{$\begin{array}{l}\text { Eiserner- } \\
\text { Altebrücke }\end{array}$} & \multicolumn{4}{|c|}{ Kaylar } \\
\hline & -2 & -1 & +1 & +2 & -2 & -1 & +1 & +2 & -2 & -1 & +1 & +2 & -2 & -1 & +1 & +2 \\
\hline Ulaşılabilirilik & & & & $\bullet$ & & & & $\bullet$ & & & & $\bullet$ & & & & $\bullet$ \\
\hline Erişilebilirlik & & & - & & & - & & & & & & - & & & & - \\
\hline Okunabilirlik & & & - & & & & & - & & & - & & & & $\bullet$ & \\
\hline Bağlantılar & & & & • & & - & & & & & - & & & & & - \\
\hline Aktivite Çeşitliliği & & $\bullet$ & & & - & & & & & & $\bullet$ & & & & & • \\
\hline Aktifik & & & $\bullet$ & & & & $\bullet$ & & & & - & & & & & - \\
\hline Sürdurülebilirlik & & - & & & & - & & & & - & & & & - & & \\
\hline Mekanın Farklı Kullanımı & & - & & & - & & & & & & $\bullet$ & & & & & - \\
\hline Mekanin Sosyal Kullanımı & - & & & & & & $\bullet$ & & & - & & & & & & $\bullet$ \\
\hline Kapsayıcılik & & & & - & & & & $\bullet$ & & & & $\bullet$ & & & & $\bullet$ \\
\hline Etkileşimli Alan & & & $\bullet$ & & & $\bullet$ & & & & & $\bullet$ & & & & & $\bullet$ \\
\hline Rekreasyon için Uygunluk & - & & & & - & & & & & - & & & & & & - \\
\hline Güvenlik & & & $\bullet$ & & & $\bullet$ & & & & & & - & & - & & \\
\hline Bakim ve Temizlik & & & & - & & & & $\bullet$ & & & & - & & & - & \\
\hline Caziplik ve Çekicilik & & & & - & & & & $\bullet$ & & & & - & & & & - \\
\hline Yapım Kalitesi-Doku & & & - & & & & $\bullet$ & & & & & - & & & & $\bullet$ \\
\hline Donatı Yeteriliǧi & & $\bullet$ & & & $\bullet$ & & & & & & - & & & $\bullet$ & & \\
\hline Sonuç & & + & & & & + & & & & + & 18 & & & & 23 & \\
\hline
\end{tabular}

Şekil 18. Araştırma Değerlendirme Tablosu

Römerberg Meydanı, aydınlatma üniteleri, çöp kutuları, ulaşım ağlarına yakınlığı ve sınırlarının tanımlanması açısından yeterli bulumuştur. Ancak bilgilendirme panoları ve yönlendirme levhaları açısından yetersizdir. Diğer meydanlar kıyı bağlantıları ve sokakların merkeze bağlantısı kuvvetlidir. Aynı zamanda meydanda vakit geçirmek için gerekli olan kent mobilyası sayısı da yetersiz bulunmuştur. Meydan bu sebeple bir duraklama noktası olmak yerine daha dinamik bir geçiş alanı olarak işlemektedir. Bir kısmı yarı kamusal alan olarak hizmet veren alanda kafeler, minik mağazalar ve restoranlar meydanın canlı olmasını destekler. Ancak farklı kullanım olanaklarına yeterince esnek değildir. Meydan Dom Meydanı'na doğru 1 - 1.5 m yükselen bir eğime sahiptir. Meydan engelli kullanımı ve erişilebilirlik açısından asansörler, geniş açıklıklar rampalar ile desteklenmiştir ancak görme engelli biri için zeminde yapılması gereken hissedilebilir yüzeyler eksiktir.

Dom meydanı ise sınırlarının tanımsızlı̆̆ ve çevresinin kötü organizasyonu sebebiyle ikincil bir meydan olarak kalmaktadır. Yeterli aydınlatma, bilgilendirme panosu ve yönlendirmeye sahip olmasına rağmen, kaliteli kamusal mekan özellikleri göstermez. Daha çok açık olduğu saatler ve törenlerde yoğunluğu gözlemlenir. Bir kısmının demir parmaklıklar ile kapalı olması ve otopark olarak tahsis edilmiş olması meydanın açıklık hissini ve kamusal olma hissini ortadan kaldırmıştır. Bu sebeple Römerberg Meydanı'na kıyasla canlılık çok daha kısıtlı zamanlarda görülür. Dom Meydan'ı ve çevresi bisiklet park yerleri, engelli girişleri ve kullanımı açısından yeterli donanımdadır. 
Su hattına dik açıda konumlandırılan veya su hattından yayılan açık alan ağları, nehrin geçişini kutlayan kentsel yerleşimlerle 'köprü şehir' konseptiyle ilişkilendirilebilir. Bu tür yerleşimler genellikle dar geçiş yapısına girmeden önce bir eşik görevi gören kentsel meydanlarla ilişkilendirilir (Lanchester HV.1908). Eiserner Yaya Köprüsü üzerinde daha çok vakit geçirilen, akış hızı diğerine oranla daha yavaş olan bir bağlantıdır. Turistik bir çekim noktası olması, kent merkezine doğrudan bağlantısı olması ve nehir ile kurduğu ilişki açısından önemlidir. Köprü üzerinde kent silüetini anlamak ve üzerinde vakit geçirmek için uygundur. Yeterli sayıda aydınlatma, bilgilendirme panosu ve çöp ünitesi vardır. Eiserner Köprüsü üzerinde sel felaketi gerçekleşen yıllar ve su miktarının köprü üzerine ne kadar yaklaştığını gösteren bilgi panoları da içerir. Köprü engelli ulaşımı için asansörler ve rampalar ile donanımlıdır ve köprünün başında ve sonunda bisiklet parkları bulunmaktadır ve yaya kullanımı açısından yeterli donanıma sahiptir.

Altebrücke (Tarihi Köprü) ise daha çok araçlar için kullanılan bir köprüdür. Aydınlatma üniteleri, üzerindeki oturma dinlenme cepleri ve çöp kutuları ve bisiklet parkları ile yeterli sayıda donanıma sahiptir. Maininsel adasına bu köprü üzerinden bağlantı sağlanmaktadır. Önceden bir kamusal alan olmasına rağmen ada üzerine yapılan yapı ile birlikte yarı kamusal bir alana dönüşmüştür. Maininsel engelli ulaşımı için köprü üstünden uygundur ancak bina ve Maininsel'e inmek çin bir rampa veya asansör bulunmamaktadır. Eski Köprü, görme engelli bireyler için zemindeki hissedilebilir yüzeyler açısından yeterlidir. Kıyılara ulaşım için gerekli rampalar ve yönelendirme levhaları açısından kamusal alanı desteklemektedir.

\section{SONUÇ:}

Kıyı sosyal yaşamımız için her türlü pozitif değeri barındırmaktadır. Su ile kurduğumuz ilişki, suya yakın olma içgüdüsü asırlardır süregelen bir bilinçaltı davranıştır. Kamusal açık alanlar, özellikle su kıyılarında insana huzur, sağlık, enerji ve yenilenme gibi hisler yüklemektedir. Özellikle nehir kıyılarında çift taraflı kıyı hattı kent için bir zenginlik sayılabilir. Robinson, nehir setlerini olumlu bir şekilde şöyle tanımlıyor: 'Her iki tarafta, şehir boyunca nehir, heybetli duvar duvarlarıyla kaplı; Adımlar ve eğimli yollar ile aralıklarla caddeye bağlanan büyük taş platformlar, ticaretin ihtiyaçlarına hizmet eder; ve yukarısında, nehir kenarında güzel bir tepe ile sınırlanan rıhtımlar, gözde bir gezinti yeri sağlar' (Robinson C.,M. 1901). Kıyıların bir bütün olarak ticaretin, cazibe noktası olmasının bir yönelim oluşturmasının açık bir tarifidir. Bu çalışma ile kamusal alan değerlendirmesi bir çizelge üzerinden gerekli kamusal konfor bileşenlerinin notlandırılması ile yapılmıştır. Yapılan analiz sonucu mevcut şartları tam sağlayan bileşenler +2 ve hiç karşılamayacan bileşenler -2 puan ile notlandırılmıştır. Analizler yerinde incelenmiş ve notlandırılmışırı. Bu çalışma kapsamında köprüler, meydanlar ve kıyılar üzerinde odaklanılmış ve kamusal alanların kıyı ile kurduğu ilişki analiz edilmiştir.

Main Nehri kıyılardaki aktiviteler ve kıyı mekanları açısından özellikle yaz ve bahar mevsimlerinde kıyıların en çok kullanıldığı dönemlerdir. Bu alanlarda doğal yaşamın sürekliliği ve kamusal alanın uygun şekilde tasarlanması ve suyun temizliği önemlidir. Alexander, kentsel alanlardaki doğal su kütlelerinin saygılı bir şekilde arıtılmasının önemini vurgulayarak, "suyun hemen yanında her zaman bir ortak arazi kuşağının korunması" ihtiyacını savunur (Alexander C, 1967). Böylece kıyıda çeşitli aktivitelerin olması hem insanlar için bir çekim noktası oluşturacak hem de kıyıda esnek ve sürdürülebilir kenarların yaratılmasına olanak sağlayacaktır. Kent özelinde kıyıların kamusal mekan kalitesi açısından yeterliliğini incelersek; Frankfurt - Main kıyıları özelinde aktivite alanları, kent mobilyaları, çöp kutuları, spor alanları, yürüyüş ve bisiklet yolları donatı elemanları açısından yeterlidir. Kıyı ulaşım araçları tramvay, otobüs, bisiklet ve metro ile kolayca sağlanmaktadır ve yeterli sayıdadır. Ancak kıyının taşma ve sel açısından tasarım önlemleri zayıftır. Az sayıda yüzer platform ile etkinlik alanı su üzerinde bulunur. Bu noktada ördekler ve kuşlardan oluşan, doğal ortamında sürekliliğini devam ettiren kuş türlerinin olması dikkat edilmesi gereken bir noktadır. Tur botları ve etkinlikler için kafe ve kiosklar kıyıda taşınamaz durumdadır. Yükseltilmiş yol ile nehir kıyısı arasındaki alan olası bir sel ve taşma sorunları için önemli bir önlemdir. Frankfurt kıyı ve kent merkezinin kullanılması açısından ortalama bir kıyı kentinin sağlaması gereken kamusal alan özelliklerine sahiptir. Yine de değişen iklim şartları ve suyun temiz kullanımı, içindeki fauna ve canlıların yaşamının dikkatli bir şekilde incelenmesi gereklidir. Eksik görülen konfor ve kullanıcı gereksinimleri giderilmelidir, böylece kamusal alanda daha yaşanabilir ve sürdürülebilir kent kıyıları tasarlanmalıdır.

Özellikle kıyıda hareket edebilen esnek ve modern çözümler, hem suyun doğasına hem de insanın su ile olan ilişkisine katkı sağlamaktadır. Yakın gelecekte kıyıların öneminin nüfus ve iklim şartları ile değişeceği öngörülürse, kamusal kıyı alanlarının korunması, geliştirilmesi büyük önem arz etmektedir. Meydanlar, sokaklar, kıyılar arasında kopuk bir ilişli 
yerine güçlü bağlantılar ile kamusal alanların birbirine aktığı, canlılık ve cazipliğin birbirini tamamladığı mekanlar kamusal alanlarla kurduğumuz bağı güçlendirecektir. Main nehri Frankfurt için önemli bir cazibe noktası oluşturmaktadır. Ancak kentin bu durumdan yeteri kadar iyi faydalanabildiği söylenemez. Kıyı boyunca çok az sayıda su üzerinde ya da su kıyısında etkileşim alanı bulunur. Kıyı daha çok yürüyüş, dinlenme ve spor etkinlikleri için ayrılmışıı, köprülerin kıyı ile bağlantı noktalarında rekreasyon alanları bulunmaktadır, ancak bu alanların kıyı ile kurduğu bağlantı stabildir. Gelişen teknoloji ve malzeme bilgisi ile suya dayanıklı ve su ile sağlıklı ilişki kurabilen platformlar, su üzerinde nefes alabilen malzemeler ile rekreasyon alanları sadece kıyıda değil su üzerinde de organize edilebilmektedir. Su içerisine uzanan setler ile kıyıdan suya bakmak yerine suya dokunmak veya su sporları için bu setleri oluşturmak yeni aktivitelere temel oluşturmak mümkündür.

\section{Etik Standart ile Uyumluluk}

Çıkar Çatışması: Yazarlar herhangi bir çıkar çatışmasının olmadığını beyan eder.

Etik Kurul İzni: Bu çalışma için etik kurul iznine gerek yoktur / Finansal

Destek: Yoktur.

\section{KAYNAKÇA:}

Alexander, C.; Ishikawa, S.; Silverstein, M. A Pattern Language; Towns-Buildings-Construction; Oxford University Press: New York, NY, USA, 1977.

Breen, A., \& Rigby, D. (1996). The New Waterfront. Singapore: Mc Graw Hill.

Bruttomesso, R. (2001). Complexity on the urban waterfront. In R. Marshall (Ed.), Waterfronts in Post-Industrial Cities. New York: Taylor \& Francis.

Carr, S., Francis, M., Rivlin, L.G. ve Stone, A. M. (1992). Public spaces. Cambridge: Cambridge Üniversitesi.

Carr, S., Francis, M., Rivlin, L.G., Stone, A.M., (1992), Public Space. Cambridge: Cambridge University Press.

Çelik F., Erdönmez E. (2016) Kentsel Mekanda Kamusal Alan İlişkileri, Y1l 2016, Cilt, Sayı 14, 145 - 163, 01.09.2016/ Madden, 2001,: 11-20)

Gehl, J. 2001. Life Between Buildings (5th Edition), Danish Architectural Press, Copenhagen.

Hakyemez, D. 1987. "Kıyılarımızın sorunu: Tanımsızlık" adlı yazı, Bilim ve Teknik Dergisi, Sayı: 230, İnceoğlu, M., Aytuğ, A., Kentsel Mekânda Kalite Kavramı, Megaron Dergisi, 4,3, 2009,131-146.

Kılıç, A., Akın, O., Koç, E., (2016) Kıyı Alanlarına Yönelik Yasal ve yönetsel çevçevenin planlama yansımaları: Yasalar, kurumlar ve parçalanmış kıyı mekanı, Yıldız Teknik Üniversitesi, Mimarlık Fak. Şehir ve Bölge Planlama Bölümü, Beşiktaş - İstanbul, Türkiye.

Kılınç C., İnceoğlu M., Balçık S.,ALKU Journal of Science 2021, Sayı 3(2): 50-63 e-ISSN: 2667-7814

Köseoğlu, Emine, 2012, Kurgusal Olarak Farklılaşan Örüntülerde Mekânsal Okunabilirliğin Biçimsel, Dizimsel ve Öznel Boyutları, Yıldız Teknik Üniversitesi, FBE, Mimarlık Anabilim Dalı, İstanbul. Lanchester, H.V. Park

Systems for Great Cities. Builder 1908, 95, 343-348.

Lynch, K, (1984), Good city form, Cambridge, Mass.: MIT Press.

Lynch, K., Good City Form, MIT Press, Cambridge, Mass; içinde, İnceoğlu, M., Aytuğ, A., Kentsel Mekânda Kalite Kavramı, Megaron Dergisi, 4,3, 2009,131-146.

Nasar J.L., (1998), The evaluative image of the city Thousand Oaks, CA: Sage Publications. Nasar J.L., (1988), Environmental aesthetics: theory, research, and applications, Cambridge: Cambridge University Press. 
Rapoport, A., (1982), The meaning of the built environment: A nonverbal communication. Beverly Hills, CA: 145 Sage Publications

Robinson, C.M. The Improvement of Towns and Cities or The Practical Basis of Civic Aesthetics; G.P. Putnam's Sons: New York, NY, USA, 1901. [Google Scholar]

Voordt, D. J. M. van der, (2005), Architecture in use: an introduction to the programming, design and evaluation of buildings / Amsterdam: Architectural Press.

Şekil 1. Mekansal Kalite Göstergeleri (Van d.V.T.J.M, Van W. H.B.R., 2005) / Spatial Quality Parameters (İnceoğlu 2007 ve Voordt 2005)

Şekil 2. Frankfurt Kent Tarihi, Erişim Tarihi: 25.11.2021 https://prezi.com/rgs-hc_wmb9x/die-stadtentwicklungvonfrankfurt/

Şekil 3. Frankfurt 2021, Stadtplannungsamt Kentin Yapılaşma Haritası Erişim Tarihi 17.12.2021 https://geoportal.frankfurt.de/karte

Şekil 4. Frankfurt Innenstadt-Altstadt ve Main Nehri Morfolojik Yapısı Erişim Tarihi: 11.11.2021 https://docplayer.org/48368610-Stadtentwicklung-frankfurt-am-main-die-leitprojekte-martinhunscherstadtplanungsamt-frankfurt-am-main.html

Şekil 5. 1890-1900 arası Nikolai Kilisesi ve Adalet Çeşmesi Erişim Tarihi: 15.11.2021 https://commons.wikimedia.org/wiki/File:Romerberg_and_Nicholas_Church,_Frankfort_on_Main (i.e.Frankfurt_am_Main),_Germany-LCCN2002713664.jpg

Şekil 6. Römerberg Meydanı, Rekontrüksiyon Çalışmaları Sonucu https://jordanrec.com/archives/57519

Şekil 7. Frankfurt Katedrali ve Eiserner Köprüsü Erişim Tarihi:

19.11.2021 https://vielunterwegs.de/reiseziele/deutschland/frankfurt-ammain/sehenswuerdigkeiten/

Şekil 8. Ersin Abay_ Kıyı Analiz Eskizleri

Şekil 9. Ersin Abay_ Bağlantı Yolları Analizi

Şekil 10. Frankfurt Tarihi Köprü ve Maininsel Erişim Tarihi: 11.12.2021 https://www.dreamstime.com/photosimages/bridge-over-main-river-frankfurt-germany.html

Şekil 11. Frankfurt Main Nehir Kıyısı ve Parklar Erişim Tarihi: 08.11.2021 https://www.frankfurtgreencity.de/en/berichte-uebersicht/status-and-trends/climate-and-open-spaces/renewingfrankfurts-energy/

Şekil 12. Römerberg Meydanı, Dom Meydanı ve Pauls Meydanı Erişim Tarihi: 15.11.2021 http://cargocollective.com/borgarmynd/Frankfurt-3d-Map

Şekil 13. Ersin Abay_Römerberg Meydan Analizi

Şekil 14. Ersin Abay_Kent Doku Analizi

Şekil 15. Eiserner Steg / Sachsenhausen Tarafından Kente Bakış Erişim Tarihi : $\quad$ 01.12.2021 https://www.hotel.de/blog/frankfurt-sachsenhausen/

Şekil 16. Ersin Abay _ Kıyı Donatı Aktivite Analizi

Şekil 17. Main Nehri Açık Mekanlar Erişim Tarihi: 02.12.2021 https://www.alamyimages.fr/photo-imageallemagnehesse-frankfurt-am-main-main-cafe-a-frankfurt-promenade-riverside-85978020.html

Şekil 18. Ersin Abay, Mehmet Can Altun, Görsel Çevrede Etki Analizi Beşiktaş Meydanı Örneği, Anket Çalışması 